\title{
Digging without Dirt: Adriaan Reland's Explorations of the Holy Land
}

\author{
Ulrich Groetsch
}

Adriaan Reland was, without question, a seminal figure in the Early Modern study of Arabic and Islam. ${ }^{1}$ He seamlessly fits into a tradition of Early Modern scholarship that started with figures such as Thomas Erpenius (1584-1624) and Jacob Golius (1596-1667) and includes doyens in the field such as Johann Heinrich Hottinger (1620-1667), Georg Sale (1697-1736) and Johann Jacob Reiske (1716-1774). ${ }^{2}$ Obvious economic and political considerations notwithstanding, Early Modern interest in Arabic studies, and the Arabic language in particular, cannot be dissociated from its theological relevance. ${ }^{3}$ Aside from the fact that an understanding of Islam was perceived as essential for Christian writers in their polemical effort to disavow the most recent Abrahamic religion, Arabic's close relationship to Hebrew was seen as an important avenue to illuminate the intricacies of sacred scripture. No matter how uniquely openminded Reland's study and perception of Islam may have been, he remained, to the core, a professor at a university steeped in a long history of theological debates. ${ }^{4}$ From 1713 , Reland was also a formal member of a society for the advancement of Christianity. ${ }^{5}$ Indeed, Reland himself re-emphasized the

1 I am grateful to my father, Franz-Xaver Grötsch, who overcame the extremely adverse circumstances of his upbringing during and after the War in Germany. Although he never became an academic, his training in Latin and Greek at the old German Gymnasium in the Bavarian boondocks puts my own linguistic training to shame, and the father, at the age of 81 , continues to exceed the son.

2 On the subject, see Bevilacqua, Republic of Arabic Letters.

3 The scholarly literature on the subject of Early Modern European interest in Arabic and the Islamic world has virtually exploded during the past two decades. For matters of brevity, see contributions in Loop, Hamilton and Burnett, The Teaching of Arabic in Early Modern Europe; on the economic and political implications, see for instance Zwierlein, Imperial Unknowns; Vrolijk and van Leeuwen (eds), Arabic Studies in the Netherlands; Klein and Platow (eds), Wahrnehmung des Islam zwischen Reformation und Aufklärung.

4 On the 'Reland turn' in the perception of Islam, see Stroumsa, A New Science, pp. 136-137 as well as Bevilacqua, Republic of Arabic Letters, pp. 83-85.

5 [Nicéron], Mémoires pour servir a l'histoire des hommes illustres dans la Republique des Lettres (1729), vol. 1, p. 335: 'En 1713. on établit en Angleterre une Societé pour l'advancement

(C) ULRICH GROETSCH, 2021 | DOI:10.1163/9789004462175_009

This is an open access chapter distributed under the terms of the CC BY-NC 4.o license. Groetsch - 9789004462175 
theological grounds for the utility of the study of Arabic in the preface to his seminal De religione Mohammedica (1717) — to illustrate difficult passages in Scripture that the Jewish interpreters no longer understood themselves. ${ }^{6}$ In this regard, Arabic, just like Syriac, Ge'ez, or Coptic, becomes a 'handmaiden' to theology and falls in line with the voluminous biblical scholarship of Samuel Bochart (1599-1667), the Polyglot Bibles of Paris, Antwerp, and London, and the seminal philological work on the Book of Job of Albert Schultens (16861750). ${ }^{7}$ It rests on the non-negotiable premise that 'the codices of the Old and New Testaments contain characters of divine origin', as Reland pointed out, reiterating what Protestant theologians had emphasized decades before him. ${ }^{8}$

When Reland assumed his professorship at the University of Utrecht in 1701, the gun smoke of the heated debates about the genuine text of the Bible had barely dissipated. The disputes had reached new heights with the attacks of the Oratorian priest Jean Morin on the Hebraica veritas during the 1620 and had culminated in the controversies surrounding the publication of Louis Cappel's Critica sacra (1651) and Hugo Grotius's Old Testament commentaries in $1644 .{ }^{9}$ Not surprisingly, the Protestant orthodoxy during the seventeenth and eighteenth centuries reasserted the integrity of the biblical text. Even decades after these controversies, orthodox theologians such as Johann Gottlob Carpzov (1679-1767) of Leipzig seriously grappled with the arguments of Cappel and others. The orthodoxy did not welcome a new wave of religious heterodoxy that would shake the foundations of Scripture. ${ }^{10}$ Figures such as William Whiston (1667-1752) or Jean Le Clerc (1657-1736), who had dared to embrace

de la Religion Chretienne, l'année suivante il s'en forma une autre pour la propagation de l'Evangile dans les Païs Etrangers. M. Reland fut associé à l'une \& à l'autre'.

6 Reland, De religione Mohammedica, and edn., Praefatio, fol., ********2: 'Sed, an theologo haec vox proficisci potest? Unde tot loca difficilia, tot $\ddot{\alpha} \pi \alpha \xi \lambda \varepsilon \gamma o ́ \mu \varepsilon v \alpha$, quae Judaei ipsi fatentur se non intelligere, in Jobo, in Prophetis, in aliis S. Scripturae libris lucem accipiunt, nisi ex lingua Arabica?'

7 Schultens, Opera minora, as well as idem, Commentarius in Librum Jobi; on the subject, see Schenker, 'The Polyglot Bibles'; Shalev, Sacred Words and Worlds; also Dunkelgrün, 'The Multiplicity of Scripture'.

8 Reland, De religione Mohammedica, fol. ******2 2 r: 'Nostri codices Veteris \& Novi Testamenti omnes characteres divinae originis habent quos vel Mohammedanus vel quivis alius desiderare potest $[\ldots]$ '.

9 On these subjects, see Hardy, Criticism and Confession, pp. 249-274 and 308-361.

10 See, for instance, Carpzov, Critica sacra, 'Praefatio', fol. biv.: 'Ille enim [William Whiston], cum novo post Cappellum, Is. Vossium, Rich. Simonium, Paul. Pezronum, impetu in Scripturam S. involasset, \& hinc integritatem eius multis in locis, dudum, alias vexatis pariter ac vendicatis, solicitasset, hinc de versionibus, de Masora, de punctis Vocalium \& Accentum apud Hebraeos, aliisque Criticae capitibus perverse ac temere, \& eum omnino in modum disseruisset, quo convicium fieret Scripturae [...]'. 
the work of earlier critics such as Cappel, Grotius, or Richard Simon (16381712), were often mentioned in the same breath as Spinoza or John Toland (1670-1722), the arch-foes of revelation..$^{11}$ Orthodox theologians, regardless of their whereabouts, reemphasized principles of exegesis that had been laid out by first-and second-generation Reformers such as Matthias Flacius (1520-1575) or Salomon Glassius (1593-1656). ${ }^{12}$ In his seminal Clavis Scripturae (1567), the Istrian Reformer Flacius had noted that the blame for the supposed obscurity of Scriptural passages lay with the exegete, not with divine revelation. ${ }^{13}$ According to Flacius, there were many reasons for a certain degree of obscurity of Scripture, but the main reason was our own ignorance. ${ }^{14}$ In fact, the 'main source for the difficulty of Holy Scripture was', as Flacius wrote, 'that theologians have never striven with utmost diligence to understand Holy Scripture itself and its text more perfectly or to explain it to others.' ${ }^{15}$ Flacius emphasized that the Holy Spirit was both author and exegete, and would lead us to truth. In regard to the Old Testament, Flacius identifies a double Mosaic veil making it difficult to discern the Old Testament's true meaning. ${ }^{16}$

To lift this veil we must make an effort to understand properly Ancient Jewish Ceremonial Law and to look for guidance in Christ, the ultimate goal of Scripture. As Paul had emphasized, salvation does not occur through the Law

11 Carpzov, Critica sacra, 6: 'Iure suo, eo quidem nomine vapulat Ludovicus Capellus, ingentium vir meritorum, ni nefandam in eo posuisset operam, ut corrasis undique, fictisque \& obtrusis observationibus Criticis, sacrum Codicis Hebraei textum, in summum adduceret discrimen. Lubrica isthaec \& inauspicata vestigia improvide preferunt Joannes Morinus, Claudius Cappellanus, Hugo Grotius, Richardus Simonius, Joannes Clericus, P. Pezronus, aliique $[\ldots]$ '.

12 On Glassius, see Bultmann and Danneberg (eds), Hebraistik—Hermeneutik—Homiletik; on Flacius, see for example, Ilic, Theologian of Sin and Grace; on the typological and allegorical exegesis among Lutheran orthodoxy, see Steiger, 'The Development of the Reformation Legacy'.

13 See Flacius, Clavis Scripturae, p. 2: '[...] sed quod, nostra culpa, non ubique ita apertus nobis eius sermo ac sensus videtur, ut in multis aliis scriptoribus. Quae non eo a me dicuntur, ut vel impiis calumniandi Sacras literas occasio detur: vel quisquam ab earum studio absterreatur: sed contra, ut tanto magis diligentia Lectorum excitetur; utque, observatis hisce difficultatibus, tanto exactius postea remedia, quae proponam, perdiscantur'.

14 Ibid., p. 2: 'Sermo est non nihil obscurus, cuius rei multae sunt causae, de quibus mox dicam; praecipue autem nostra eius imperitia'.

15 Ibid., p. 7: 'Hic enim ferme primarius fons est difficultatis Sacrarum literarum: quod propemodum nunquam Theologi summa diligentia in id incubuerunt, ut perfectius, vel congnoscere ipsi, vel aliis explicarent, ipsum Sacrum sermonem aut textum [...]'.

16 Ibid., p. 6o6: 'Velamen Mosis, est quaedam obscuritas Legis, ut eius primarius, verus, ac genuinus sensus aut scopus, non plene aut perspicue perspici possit. Id vero duplex est, teste Paulo, 2. Cor. 3, 13, 14'. 
of the Old Covenant but through Christ alone. ${ }^{17}$ Likewise, over fifty years after the publication of Flacius's Clavis, the Lutheran sage Salomon Glassius iterated similar premises in his widely circulated Philologia Sacra (1623). Against all critics and polemicists, he reaffirmed the divine origin of the Hebrew and Greek Testaments, the 'fount of all holy tenderness and the bubbling spring of the water of life.'18 Glassius essentially dismissed the argument of critics who bemoaned that Scripture was contradictory and obscure. He pointed out that potentially problematic passages were few and far between and of little dogmatic value anyway. ${ }^{19}$ Especially with regard to the Old Testament, the application of the New Testament served as the panacea. ${ }^{20}$ Just like Flacius before him, Glassius stressed the twofold sense of Scripture: the literal sense and the mystical or spiritual sense. While the literal sense referred to the immediate and obvious (e.g. Jonah was three days and three nights captive inside the big fish), the same words simultaneously served to deliver a deeper meaning (e.g. Christ spent three days and three nights in the grave).$^{21}$ Under the sensus mysticus, Glassius argued, fell the sensus typicus, which specifically referred to events and stories in the Old Testament that foreshadowed Christ's life, passion, death, and subsequent glory. This was already stated explicitly in Romans 5:14, which refers to the biblical Adam as 'the figure of him that was to come.22 In order to grasp such references, however, the exegete must

17 Ibid., p. 611: 'Detraxit igitur, in novo Testamento, Christus, huius Populi Rex \& Dominus, velamen Mosis, in judiciali aut Politica Lege [...]. Docet enim is, Act. 13. v. 38. 39. Homines non potuisse justificari, ac liberari a peccatis, per Legem; sed per Christum liberatos esse'. Glassius, Philologia sacra, p. 1: 'Dulcius, addo \&, purius ex ipso fonte bibuntur aquae. Fons omnis dulcedinis sanctae \& aquae viventis scaturigo, est Hebraea Veteris; \& Graeca Novi Testamenti veritas $[\ldots]$ '.

19 Ibid., p. 282: 'Objiciat quis, quaedam nihilominus in Scripturis obscuro \& perplexo sermonis genere proponi [...]. 1. Pleraque illorum non concernunt dogmata fidei. 2. Et pauca sunt, a quibus ad Scripturam universam nullus consequentiae nexus [...]'.

$20 \quad$ Ibid., p. 267: ‘[...] Cum causas illas ó $\mu \omega v v \mu i \omega \hat{\nu}$ in Vet. Testam. tantum stylo locum habere asserat; fateatur ergo genus sermonis, quo Spiritus S. in Nov. Test. scriptis utitur, planum, perspicuum, \& ab ambiguitatibus liberum esse, praesertim cum No.Test. (dicente saepius LUTHERO) sit instar Solis, quae V.T. ceu Lunam splendore suo illustrat'.

21 Ibid., pp. 349-35o: 'Est enim Sensus literalis is, qui proxime \& immediate per ipsa verba, sive sint propria sive modificata, significatur, ut Jonas tribus diebus \& tribus noctibus fuit in visceribus piscis. Jon. II.1. Hic sensus literalis est, qui proxime ex ipsis verbis eruitur, ut Jonas intelligatur Propheta ipse, qui suam descripsit historiam [...]. Sensus mysticus est, qui non significatur proxime per ipsa verba, sed per rem ipsis verbis significatam. Sic sensus mysticus in texto paulo ante allegato est is, quod Christus tribus diebus \& tribus noctibus futurus sit in sepulchro, in morte sua'.

22 Ibid., p. 443: 'Theologi hoc in negotio per Typos nihil aliud intelligunt, quam rerum sive praesertim sive futurarum imagines \& figuras; \& praesertim facta \& historias V.T. quae ad Christum Salvatorem in N.T. exhibendum respexerunt, eum que in actionibus, vita, passione, morte, \& subsequente gloria praefigurarunt. Quo sensu appellationem hanc 
have acquired a profound understanding of the biblical text in its original languages. This required an expert knowledge of Hebrew and Greek grammatical and literary devices, ranging from simple ellipses to metonymy, synecdoche, paronomasia, and antanaclasis.

The principles laid out by Flacius and Glassius transcended Protestant theologians' denominational divide. In Franeker, the doyen of prophetic theology Campegius Vitringa (1659-1722), professor of Oriental languages, included numerous scholarly treatises on Old Testament typology in his two volume Observationum sacrarum (1683-1708). ${ }^{23}$ Vitringa's colleague at Franeker and scholarly nemesis was the extremely prolific Hebraist Jacob Rhenferd (1654-1712). In 1704, Rhenferd published his Dissertatio De ratione observandi genuinam vocabulorum Hebraicorum significationem [Treatise on the reason for complying with the true meaning of Hebrew vocabulary], and upon his retirement from the rectorate, he laid out the principles of the philologia sacra in his parting speech, Oratio De fundamentis \& principiis philologiae sacrae (1710) [Discourse on the fundamentals and principles of sacred philology]. ${ }^{24}$ Rhenferd was also working on a comparative grammar of Arabic, Aramaic, Syriac, and Hebrew. The outline for the book, with its heavy emphasis on Hebrew and its frequent references to the biblical text, suggests that Rhenferd viewed this work as a future tool for the biblical philologist. ${ }^{25}$ In Groningen, the Hebraist and biblical scholar Johann Braunius (1628-1708) reiterated many of the principles laid out by Flacius and Glassius in his systematic theology. Braunius stressed that Scripture, as the word of God, was the only true source of theology and the Christian faith. ${ }^{26}$ Since the Holy Spirit guided the hand of the amanuenses, Scripture in all its parts was perfect and without error. ${ }^{27}$ From this perfection, Braunius imbued a clarity in meaning of the biblical text, although the human mind, due to its inferiority, may be challenged in interpreting the text correctly. ${ }^{28}$ To communicate his word, God adopted the vernacular of the people he was addressing. As the first language created by God,

Érypayov esse quidam existimant, hucque referunt dicta Rom. v.14. ubi Adam primus homo

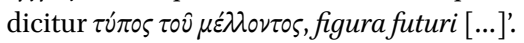

See for instance, Vitringa, 'Typi crucifixioni Christi', in his Observationum sacrarum, vol. 1, pp. 409-419; on Vitringa, see Telfer's somewhat overdramatic Wrestling with Isaiah.

24 Rhenferd, Dissertatio philologica; idem, Oratio De fundamentis, pp. 917-941.

25 Idem, Rudimenta grammaticae, pp. 828-886.

26 Braunius, Doctrina foederum, p. 11: 'Unicum igitur atque Verissimum principium Theologiae \& Religionis salutaris Revelatae, est verbum Dei'.

27 Ibid., p. 17: 'Erant igitur Sacri Scriptores organa \& amanuenses, quibus Spir. S. in tradenda Sacra Scriptura usus est. Ut nec voluerint, nec potuerint, errare viri $\theta \varepsilon o ́ \pi v \varepsilon v \sigma \tau o l '$.

28 Ibid., p. 25: 'Cum Scriptura S. sit perfecta, sequitur eam etiam esse perspicuam [...]. Deinde certum est mentem nostram occoecatam, immo mortuam esse per peccatum: Ephes.2:1. ut non possimus capere ea quae sunt Spiritus Dei. 1 Cor.2:14'. 
the Hebrew language was thus perfect and the basis of all other languages. ${ }^{29}$ Just like his Lutheran predecessors Flacius and Glassius, Braunius equally distinguished between the sensus literalis and the sensus mysticus. ${ }^{30}$ Although Braunius acknowledged that the ceremonial law of the Old Testament lost its practical relevance with the implementation of the New Law, it maintained its relevance as a bearer of a typological and prophetic meaning. ${ }^{31}$

Those were roughly the theological boundaries that delineated the field of scholarship which Reland and his early eighteenth-century colleagues at Utrecht occupied. ${ }^{32}$ It was an overall theologically conservative environment where the purity and infallibility of Scripture was guarded carefully and maintained among all Protestants. ${ }^{33}$ Nor was this intellectual space confined by national boundaries. It was not a universe that was exclusively Dutch, German, French, Italian, or English, as some recent publications in the field would like us to believe. ${ }^{34}$ It was part of a 'global' Protestant Republic of Letters, in which biblical scholars quibbled and quarreled. ${ }^{35}$ Of course, denominational doctrinal disputes within Protestantism remained and included mutual defamations and accusations of heterodoxy and Spinozism. ${ }^{36}$ These theological debates and boundaries, however, did not inhibit scholarly production. On the contrary. Reland's scholarly universe should be classified as the 'golden age of biblical scholarship' ${ }^{37}$ In their attempt to refute real and imaginary attacks

29 Ibid., p. 28: 'Hebraea lingua est perfectissima, ut nulla ostendi possit perfectior, quae naturam rerum perfectius \& accuratius exprimat [...]. Omnes fere gentes totum terrarum orbem nomina sua habent ex lingua Hebraea, quae exstat in Scriptura S. [...]'.

$30 \quad$ Ibid., p. 33: 'Cum S. Scriptura sit legenda \& vertenda, sequitur eam etiam esse interpretandam, \& eius sensum indagandam. Est autem sensus Scripturae literalis, vel mysticus'.

31 Ibid., p. 42: 'Ubi autem est exactissima convenientia inter typum \& antitypum, picturam \& rem depictam, id est inter praedictionem \& eventum aliquem particularem, isti praedictioni respondens secundum omnes circumstantias sive rationes, ibi necessario debet esse complementum istius praedictionis, adeoque verus sensus Prophetiae'; ibid., p. 504: 'Hinc Principes huius saeculi dicuntur, id est saeculi Veteris Testamenti, qui debebant aboleri. 1 Cor. 2:6'.

32 By far the best contextualization of theological patterns and scholarship is Levitin's 'From Sacred History to the History of Religion'. Somewhat helpful for the Dutch context is Touber, 'Biblical Philology and Hermeneutical Debate in the Dutch Republic'.

33 Spinoza (like all freethinkers) was an anomaly and was perceived as an arch-foe of revelation. Protestant scriptural interpretation, by and large, remained in very strict boundaries, its Lutheran or Reformed provenance notwithstanding.

34 Touber, Spinoza and Biblical Philology; Van Miert, The Emancipation of Biblical Philology.

35 Still seminal is Goldgar's Impolite Learning.

36 See, for instance, my article on the Lutheran polemicist Sebastian Edzard, entitled 'Adversus Haereticos: Sebastian Edzard's Epic Battle for Souls', at p. 137.

37 I believe that there is enough evidence that this period could be called the 'golden age of biblical scholarship', as opposed to 'biblical criticism in the Dutch Golden Age' (see n. 34 above). 
from theological opponents such as Roman Catholics and freethinkers and to prepare future generations of Protestant theologians and preachers of the sacred word, Christian (mainly Protestant) Hebraists produced a massive body of biblical scholarship. The message across the board was always the same: the Hebrew Bible was literally true and the biblical text was without error and should be interpreted in accordance with the principles of the philologia sacra outlined above. At the same time, obscure passages could be unlocked with the help of auxiliary, profane disciplines. Accordingly, it was perfectly legitimate to elucidate the sacred text with the help of the sciences, geography, or other (Semitic) languages, as long as the textual integrity was not violated. The idea was 'to employ rather than enjoy' profane disciplines, as the pastor from Magdeburg, Johann Justus von Einem declared succinctly. ${ }^{38}$

This meant that the events recorded in the biblical text were not just plausible as the amanuenses had recorded them, but literally true. Eden was a real place that could be located on a map, as was the $\operatorname{Re}(e) d$ Sea or Mount Sinai. As a consequence, the seventeenth and eighteenth centuries witnessed a flood of publications and commentaries on virtually every aspect of Scripture. A testimony to the breadth (and depth) of this scholarly enterprise are Johann Albert Fabricius's Bibliographia Antiquaria (1713) and, somewhat later, Blasius Ugolini's massive Thesaurus Antiquitatum Sacrarum (1744-1769). Ranging from broad subjects such as the geography of the Holy Land to more specific ones such as the uses of acacia wood in ancient Hebrew construction, the value of ancient Hebrew monetary units and coins, or the design of King David's lyre, Early Modern savants covered virtually every aspect of Scripture in general, and biblical Israel in particular. This body of 'antiquarian' scholarly literature, be it the short philological treatises on a single contested Hebrew word in the Bible or hefty monographs on any aspect of ancient Israelite culture, was incorporated in the erudite theological commentaries and treatises with the impressive scholarly apparatuses so typical of the late seventeenth and eighteenth centuries such as the series of commentaries by the Arminian Jean Le Clerc or the Benedictine Calmet. ${ }^{39}$ Reland was an active player in this world: he 'mapped Paradise', identified the Re(e)d Sea of the Exodus, and demonstrated his antiquarian skill in his learned treatises on Samaritan coins. ${ }^{40}$

A glimpse of Reland's early scholarly promise is provided by a public disputation that was directed in 1696 by Reland's mentor, the formidable and quarrelsome Melchior Leydecker (1642-1721). ${ }^{41}$ When Reland came to Utrecht,

\footnotetext{
38 Von Einem, Selectae animadversiones, p. 65: 'Profanis auctoribus utamur, non fruamur'.

39 See, for example, Calmet, Commentaire literal, or Le Clerc, Commentarius in Mosis.

40 See, for example, Scafi, Mapping Paradise.

41 On Leydecker see Van Asselt, 'Leydekker'; Hoek, 'Leydecker'.
} 
the Leydeckers took the young student into their home. Although it was very common for professors to have students board with them, those who secured such a spot enjoyed additional opportunity for intellectual exchange and, ideally, access to the professor's library. Access to resources required influence in the Republic of Letters and a glowing recommendation from a student's previous teachers certainly did no harm. It was undoubtedly helpful if the student's teacher had considerable standing in the Republic of Letters, which was anything but a community of equals as both Anne Goldgar and Lawrence Brockliss have so convincingly demonstrated.$^{42}$ Not unlike today, where academic success is also determined by class and access to resources at an early age, this inequality during the Early Modern period was perpetuated by the concentration of resources at a few select centres of learning and the incestuous relationship of academic elites, exemplified by the scholarly dynasties of the Buxtorfs, Vossii, Cappels, Hottingers, Gronovii, Spanheims and many others. Less privileged students were often ill-prepared for the academic challenges at institutions of higher learning and, while struggling through a propaedeutic course of study, could only hope to catch the attention of one of the professors, who would recognize their talent and would be inclined to be their mentors. ${ }^{43}$ That such a stroke of luck would happen was much more likely in the setting of private teaching, which ensured a more intimate connection with the professor, but which required the payment of an additional fee, thus putting students with lesser means at a disadvantage. ${ }^{44}$ Much of such a 'stroke of luck' depended on the skill of the student, his previous training, and his willingness to approach professors, who were often looking for assistants to organize their library, buy books, or help them with their research. ${ }^{45}$ For the

\footnotetext{
42 See Goldgar, Impolite Learning, especially pp. 115-173; Brockliss, Calvet's Web.

43 See La Vopa, Grace, Talent and Merit, p. 46.

44 On private and public teaching practices see Van Miert, Humanism in an Age of Science, pp. $115^{-166 .}$

45 Johann Salomo Semler for example was extremely fortunate in gaining the attention of Siegmund Jacob Baumgarten, for whom he became a research assistant, but whose mentorship became instrumental for his studies and career. See Semler, Lebensbeschreibung, pp. 95-117: 'Den zweiten Winter fingen wir Collegia an bey dem sel. Baumgarten [...] und wir ersonnen viele Gelegenheiten, um ihn oft sprechen zu können; denn in der festgesezten Stunde, kamen wir oft nicht vor, wegen der grossen Anzahl derer, die vielleicht was für sie selbst wichtigeres anzubringen hatten. Meine Blicke waren gleichsam in seine Augen geheftet, so oft sie auch ehrerbietig sich wieder zurückzogen [...]. Da der grosse Kanzler Böhmer gestorben war, trug mir Baumgarten auf in seinem Namen ein sapphisches Trauergedicht lateinisch zu entwerfen [...] Bisher sezte ich also in Halle solche Arbeiten noch immer fort, die mir Baumgarten anwies; worunter manche Recensionen in den Nachrichten von einer hallischen Bibliothek sind [...]'; on the subject of the 'poor theology student', see La Vopa, Grace, Talent and Merit, pp. 25 f.
} 
immensely talented, though overly shy, Johann Jacob Reiske (1716-1774), for example, the studies at Leipzig during the 173 os turned out to be a nightmare. With no friend or mentor in sight, he studied mainly by himself, frequently succumbing to the temptations of different fields of interest, but never able to sustain any of them. ${ }^{46}$

The experience of Reland and Reiske could not have been more different. Reland was undoubtedly a very talented student, but he was fortunate to have access to resources of which most students could only dream. At the Athenaeum in Amsterdam, barely eleven years old, he studied under the foremost scholars of his day. Most probably Reland's rhetorical skills were polished by Petrus Francius (1645-1704), a master in the field of eloquence and poetry, and a firm believer in the pedagogical benefits of the disputation. ${ }^{47}$ Reland may have received private training in Hebrew and rabbinic literature from a young Willem Surenhusius (1664-1729), who was not yet appointed formally to a professorship, and private lessons in Arabic from Alexander de Bie (1623169o). ${ }^{48}$ It speaks for itself that Reland, at the age of thirteen or fourteen, was recruited by Surenhusius to participate in the latter's celebrated six-volume edition of the Mishna. ${ }^{49}$ This surely made an impression on distinguished professors such as Leydecker and the immensely learned Hebraist and rabbinic scholar Johannes Leusden (1624-1699), who, like Surenhusius, had acquired much of his proficiency in Hebrew (and possibly Arabic) among the Jews of Amsterdam. ${ }^{50}$ This, of course, explains why these world-renowned experts

46 See Johann Reiske, Lebensbeschreibung, pp. 8-9: 'Ich lebte für mich, studirte nach meiner Fantasie, hörte keine Collegia, hatte keinen Lehrer, keinen Anweiser, keinen Freund, fragte niemanden um Rath [...]. Ich studirte immer drauf los, ohne Ordnung und Endzweck, ohne zu wissen auf was; und ich muß gestehen, der größte Theil derer fünf Jahre, die ich als Student in Leipzig zubrachte, sind für mich verloren gegangen [...]'.

47 Van Miert, Humanism in an Age of Science, p. 151.

48 Burmann, Traiectum eruditum, pp. 293-294: 'Vix undecim aetatis annum ingressus, scholarum stadio confecto, triennium in inlustri Amstelodamensium gymnasio moratus est, ibique Petrum Francium humanitatis studia, Alexandrum de Bie, Mathesin \& Graecam linguam, Guilielum Surenhusium linguas Orientales, Judaicasque antiquitates docentes, audivit'.

49 Serrurier, Oratio funebris, p. 14: ‘[...] Gulielmum Surenhusium, nunc juris Judaici Professorem, peritia linguarum Orientalium praecellentem, sub quo biennii spatio tantos in lingua Hebraea, Syra, Chaldaea, Arabaea progressus fecit, ut Viri eruditi plane obstupefecerent, summa quaevis \& praeclara omnia hunc nostrum minari dicerent. Partem tunc operis Mischnici latine vertit'; on Surenhusius's Mishna project see van Rooden, 'Willem Surenhuys' Translation of the Mishna'.

$50 \quad$ See 'Johannes Leusden', in Allgemeines Gelehrten-Lexicon, col. 2409: 'Nach dieser verfügte er sich nach Amsterdam, und ließ sich daselbst von einigen Juden, darunter auch ein arabischer war, noch ferner in der hebräischen Sprache, desgleichen in Talmudicis und 
in the field received the 'freshman' Reland at Utrecht with open arms. When he started at Utrecht he exhibited great evidence of scholarly promise at an unusually young age. ${ }^{51}$

The topic of Reland's public debate in Utrecht in 1696 was the creation narrative in Genesis. Although authorship of the published dissertations generated by these public disputations is not always clear-both praeses and respondens could be the author-it gives us a glimpse of the scholarly standards to which Reland was held. ${ }^{52}$ The disputation lists two respondentes, Reland and a certain Adrian Pennis, of whom we know very little other than that he was originally from Rotterdam. Leydecker served as the praeses. Pennis is listed as the respondens of part one and two of the disputation, Reland as the respondens of part three and four. ${ }^{53}$ Regardless of authorship, both praeses and respondentes needed to be intimately familiar with the subject matter and capable of meticulously following the argument that was made. The printed disputations thus offer a window onto scholarly practices, familiarity with ongoing controversies, and erudition of the student body at particular institutions. The portion ascribed to Pennis is that of a solid, albeit not brilliant, student. It is theologically sound and remains within the safe boundaries of a very traditional philologia sacra. Almost all references in Pennis's work come from both Testaments and the Church fathers. Many references are in Greek, with only an occasional phrase from the Old Testament in Hebrew. The portion ascribed to Reland, in contrast, demonstrates an intimate knowledge of rabbinic sources. Its focus lies on how rabbinic scholars throughout the ages had interpreted the phrase וימר אלהים [and God said] and how God's voice or speech related to those of human beings and prophets. The treatise starts with the conundrum in the Mishnaic tractate Avot, according to which the world was created in ten utterances. The little treatise then continues, illustrating how Jewish sages often arrived at rather perplexing explanations of the creation narrative, ranging from the Mishnaic reference to the ten punishments inflicted on the wicked, to ten positive attributes associated with the divine creation process. ${ }^{54}$

in ihren Gebräuchen unterrichten, wobey er sich eine so gute Kenntniß erwarb, daß man ihn 1650 zum extraordinario, und 1651 zum ordin. Professore der hebräischen Sprachen und Antiquitäten in Utrecht bestellte'.

51 [Nicéron], Mémoires pour servir a l'histoire des hommes illustres, vol. 1, pp. 332-333: 'A quatorze ans on l'envoyà Utrecht, où il eut pour Professeurs Messieurs Graevius \& Leusden, sous lesquels il se perfectionna dans la connoissance de la Langue Latine, \& des Langues Orientales. Il y étudia aussi en Philosophie, \& y fut reçû Docteur'.

$5^{2}$ See Van Miert, Humanism in an Age of Science, pp. 149-166.

53 Pennis, Dissertationis historico-theologicae; Reland, Dissertationis historico-theologicae.

54 Ibid., fol. a2r-v: 'Praeterea in Pirke Aboth haec quaerunt ex isthac observatione mysteria. Cum verbo creari mundus potuerit, scias quantam poenam luant impii, שמאבדין את העולם שנברא בעשרת מאמרות, qui perdunt mundum, decem verbis creatum; quanta item danda 
Maimonides interpreted the Hebrew phrase וימר אלהים figuratively. The medieval Jewish philosopher argued that God did not utilize a human voice in order to express his will. This interpretation is simply a result of humanity's inability to comprehend that God's will made real — that is, made the world manifest. ${ }^{55}$ The work provides a glimpse of the unusual level of erudition the young Reland would have exhibited by the age of twenty. Aside from references to the Mishna, Maimonides, or Ibn Ezra, Reland must have been familiar with the Christian Hebraism of his day, citing Louis Cappel and John Owen specifically, and the Arabic scholarship of Johann Heinrich Hottinger (1620-1667) as well as Levinus Warner (1618-1665). ${ }^{56}$ Both corpora, the rabbinic and to a lesser extent the Arabic, are utilized to illuminate Scripture. Aside from the fact that Reland was undoubtedly gifted at an early age, talent alone was not enough to launch a career on the level of Reland's. In his case, the support and resources of scholars such as Leydecker or Leusden were vital. They provided access to books and facilitated entry into the Republic of Letters. It was probably also no coincidence that Reland continued his studies at Leiden under the illustrious Friedrich Spanheim, under whom Leydecker had studied as well.

The influence of these scholars is very apparent in Reland's work as a teacher, Hebraist, and biblical scholar. Reland's most impressive scholarly work in the field of biblical studies, his Palestina ex monumentis veteribus illustrata (1714), is a testimony to both his talent and to the excellent training he had received. It fits into the rich scholarly tradition of the Early Modern geographia sacra that had its roots in Arias Montano's Antwerp Polyglot (1568-1573). ${ }^{57}$ Among its practitioners were illustrious figures such as the French polyhistor Samuel Bochart (1599-1667) ${ }^{58}$ Bochart was one of the titans of seventeenth-century biblical scholarship. His collected works were a massive arsenal of philological knowledge about biblical geography and flora and fauna. ${ }^{59}$ Although Bochart had been dead for a decade when Reland was born, Bochart's encyclopedic scholarly output remained an important cornerstone in the field of biblical

sit merces illis, שמקימין את העולם שנברא בעשרת מאמרות qui mundum decem verbis cratum stabiliunt. Nempe nihil non inveniunt Judaei ubique, quod praebeat materiam

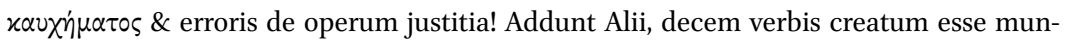
dum, uti decem מדות, attributis, qualia sunt, sapieantia, intelligentia, scientia, potentia, fortitudo, increpatio, justitia, judicium, benignitas \& misericordia'.

55 Ibid., fol. a2v.: 'Quin etiam caute Rabbi istud ויאמר ad voluntatem retulit eo sensu, quod omnia existant per voluntatem \& sententiam Dei, evitata sermonis significatione [...]'.

56 On Hottinger, see Loop, Hottinger; on Warner, see Vrolijk and van Leeuwen, Arabic Studies in the Netherlands, pp. $48-59$.

57 Shalev, Sacred Words and Worlds, pp. 23-71.

$5^{8}$ Ibid., pp. 141-203.

59 See Bochart's Hierozoicon and his Geographia sacra. 
philology throughout the eighteenth century. ${ }^{60}$ It should not surprise us that Reland, like most of his seventeenth- and eighteenth-century colleagues, could hardly avoid grappling with Bochart's scholarly output. This happened, however, almost a decade before Reland published his celebrated Palestina.

By 1706, Reland had already established more than one connection to Bochart's world. Reland dedicated his Dissertationes miscellaneae to the French man of letters and bishop of Avranches, Pierre-Daniel Huet, one of the leading figures of the seventeenth-century Republic of Letters. Huet himself had studied under Bochart, befriended him, and travelled with him to the ends of the Earth to stay with him at the court of Queen Christina of Sweden. ${ }^{61}$ The idyllic friendship between the Roman Catholic Huet and the Protestant Bochart soured after the latter accused Huet of intentionally shading Origen's meaning to advance his own doctrinal position in his newly published edition. ${ }^{62}$ Although Bochart remained indebted to him, Bochart's death and their falling out made it easier for Huet to take on his great mentor and benefactor on a scholarly level. In 1698 Huet published a lengthy scholarly treatise, entitled Tractatus de situ paradisi terrestri. ${ }^{63}$ In its preface, Huet briefly outlines the twisted course biblical interpreters had taken in their attempt to locate the biblical Eden. Similar to the continuing quest for the mythical city of Atlantis, scholars throughout history placed the biblical garden in virtually every possible space in the universe, ranging from the lunar orbit to the Arctic, America, Africa, and Asia. ${ }^{64}$ And the quest continues to this day! ${ }^{65}$ The scholarship on the subject was massive, right up the alley of Bochart's voluminous scholarly world. Huet explained that the late Bochart, whom Huet continued to praise as 'one of the most learned men of his age', supposedly worked on this

6o See Sheehan, The Enlightenment Bible, pp. 203-211.

61 On Huet see Shelford, Transforming the Republic of Letters.

62 Huet described his falling out with Bochart as follows: 'Avec l'aide de ce manuscrit, je rétablis le passage tel qu'il devait être. Mais aveuglé par l'esprit de parti et tout plein d'un zèle furieux, ne se souvenant plus ni de notre ancienne amitié, ni de l'expérience qu'il avait faite de ma nonne foi, Bochart écrivit à ses coréligionnaires, dans tous les pays de l'Europe, que j'avais falsifié Origène. J'eu un chagrin profond de cette calomnie et de l'attentat inouï fait à mon honneur par le main d'un ami; je le lui reprochai doucement, mais je n'en obtins pas la plus légère satisfaction. Ce procédé inique et barbare rompit pour jamais, à ma très-grande douleur, une amitié qui s'était affermie par un commerce de tant d'années et par tant de bons offices réciproques'. See Huet, Mémoires, pp. 97-98.

63 See Scafi, Mapping Paradise, pp. 307-313; also Massimi, 'Montrer et démontrer'.

64 Huet, Tractatus de situ paradisi, 4: 'Nihil vero melius ostendere potest, quam notus sit Paradisi situs, quam opinionum diversitas eundem investigantium. Fuere, qui collocarent eum in tertium coelum [...]. Alii eum collocarunt sub Polo Arctico [...]. Alii in Americam, alii in Africam sub Aequatore, alii ad Orientem aequinoctialem [...]'

65 Scafi, Mapping Paradise, pp. 11-15. 
project, but the outcome was more or less fragmentary. ${ }^{66}$ In fact, among the papers Bochart left behind, no such work could be uncovered ${ }^{67}$ According to Huet, judging from the savant's published work, Bochart's verdict on the location of Eden was rather ambiguous. In his Phaleg, first published in 1646, Bochart situated the elusive place in the area around Babylon. Later, however, in Hierozoicon (1663), his massive encyclopedia about the biblical flora and fauna, Bochart located it near the ancient city of Apamea in Syria. ${ }^{68}$ Following the long-winding road of philology, Huet proposed that Eden must have been located in the area between the confluence of the Euphrates and Tigris rivers and where the latter empties into the Persian Gulf. ${ }^{69}$ This verdict went back to Calvin, who placed it in Mesopotamia as well. ${ }^{70}$

When Reland entered the debate in 1706 Huet was an intellectual giant, well connected in the scholarly universe. It is not entirely clear when Reland first reached out to Huet, because none of the letters appear to have survived. The famous man of letters, politician, and antiquarian Gijsbert Cuper (1644-1716) from Deventer may have played a key role in this 'transaction.' ${ }^{71}$ Cuper was probably Reland's closest contact in the Republic of Letters. They corresponded almost on a daily basis. ${ }^{72}$ Although not the most prolific author himself, Cuper

66 Huet, Tractatus de situ paradisi, 6: 'Bochartus, iampridem defunctus, quem unum ex viris eruditissimis huius seculi fuisse existimo, persequi hoc argumentum sibi proposuerat'.

67 Huet must not have been entirely in the loop about the exact content of Bochart's estate. Although none of the surviving manuscripts of Bochart's work on Paradise are complete, the Bibliothèque Nationale holds a draft at an advanced stage. See Shalev, Sacred Words and Worlds, pp. 168-169.

68 Huet, Tractatus de situ paradisi, p. 6: '[Bochartus] aperuit quidem hac de quaestione hinc inde in operibus mentem suam, sed rationibus plane diversis, quaeque sibi contradicere videntur; nam in Phaleg Paradisum circa Babylonem ponit; at in libro De animalibus sacrae Scripturae Calvini opinioni videtur accessisse, eundem ad ripas Tigridis atque Euphratis iam conjuncti, idque Chaldaea, inter urbem Apamiam \& Sinum Persicum, constituentis'.

69 Ibid., p. 87: 'Existimamus satisfecisse nos instituto nostro, solidissimeque probasse, Paradisum terrestrem situm fuisse ad fluvium, quem confluens Tigridis atque Euphratis producit, quemque hodie fluvium Arabum appellitant, inter hanc divisionem, quam facit hic ipse fluvius, antequam se in mare Persicum praecipitat'.

$70 \quad$ See Scafi, Mapping Paradise, pp. 270-283.

71 In 1714, for instance, Cuper responded favorably to a request by the French savant Maturinus Veyssière La Croze to help a promising young student who wanted to study under Reland. He wrote: 'Je dois réponse à deux de vos Lettres; dans la prémiere qui étoit du 3o. de Juin, vous me recommandiez un Jeune * Réfugié, qui alloit avec Madame sa mere à Utrecht, pour y étudier sous Mr. Réland'. See Cuper, Lettres, p. 158.

72 Serrurier, Oratio funebris, p. 40: '[...] in Belgio nostro, praeter ingens illud nostrae patriae ornamentum, Gijsbertum Cuperum, cum quo ipsi fere quotidianum literarum commercium fuit [...]'. 
was one of the puppet masters of the Respublica literaria. ${ }^{73}$ Many of the threads of scholarly exchange passed through his hands. Evidence for Cuper's involvement in facilitating the contact between Huet and Reland comes from a letter Cuper wrote to Huet, in which he refers to Reland's treatise and desire to engage in a scholarly exchange with the great Jesuit scholar. ${ }^{74}$ Reland's dedicatory letter to Huet displays all the excessively humble submissiveness the genre prescribed: undying gratitude and friendship; exuberant praise of Huet's scholarly accomplishment; profuse apologies for adopting a different position from Huet's on the subject matter. ${ }^{75}$ It appears that Huet's response to Reland's pleas was favorable, because their relationship remained intact and remained part of Reland's scholarly network. ${ }^{76}$

The basis for 'finding Paradise' were the markers provided by Scripture. Accordingly, the garden was located 'eastward' [מקדם] 'in Eden' [בעדן]. A river ran through the garden, which parted into 'four branches' [לארבה ראשים]: the

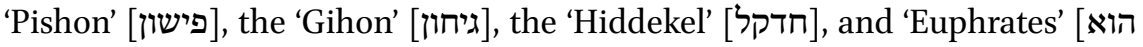

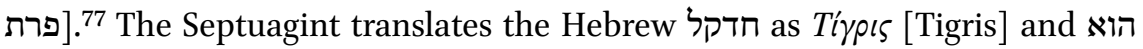

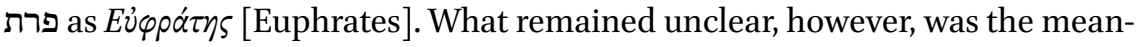
ing of Pishon and Gihon. Huet solved this problem by identifying Pishon and

73 Goldgar, Impolite Learning, pp. 26-34.

74 Cuper writes: 'Trajecti ad Rhenum publice linguas orientales docet summo cum laude Adrianus Relandus, et parat dissertationem de Paradiso; in qua in alia omnia a te facit discessionem docereque conatur hortum illum delicatum fuisse in Armenia, et inter fluvios illius refert Phasin et Araxin; quam novam opinionem quibus argumentis fulciturus sit, ego equidem capere nondum possum, neque tamen lucubrationem eam edet, antequam de placito suo tecum egerit'. See Pélissier, 'Lettres Inédites', p. 63.

75 Reland, Dissertationum miscellanearum, fol. ${ }^{*} 2 \mathrm{r} .{ }^{*}{ }^{*} 3 \mathrm{v} .:$ 'Ea est Tua eruditio, \& fama per orbem diffusa, Illustrissime Praesul, ut etiamsi nullus ante mihi patuisset ad amicitiam Tuam aditus, Tu praecipue deligendus esses, cui munusculum hoc literarium, ad consuetudinem nostrorum temporum, sacraretur [...]. Quod harum literarum omniumque bonarum artium \& scientiarum, Tu cultor, Tu patronus, Tu decus eximium sis \& ornamentum, quem ego Judicem peritiorem desiderare possem? quod idem me benevolentia tua privatim complecti volueris, quem benigniorem meorum conatum arbitrum \& interpretem exoptarem? [...] Nec tu ex illorum numero est, qui, si quis modeste a Te dissensum profiteatur, ferre illum nequeas, aut amice monere non velis, ut saniorem sententiam amplectatur [...]. Te vero, ut quicquid hoc munusculi est, Vir Illustrissime, aequo animo accipias, rogo, \& me Tui amantissimum amare perseveres, diuque Gallia Tua Te sospite fruatur'.

76 Serrurier, Oratio funebris, p. 39: 'Ingentem vobis hic catalogum exhibere possem Virorum Illustrium, ad quos frequenter a nostro literae mittebantur, a quibus etiam frequentes accipiebat; verum longum foret omnes enumerare, inter quos fuerunt in Gallia, Illustris praesul Petrus Daniel Huetius, Abbas Bignonius, Bernardus Montfauconius, Antonius Gallandius'. 
Gihon as two distributaries that emerge after the point of confluence of the Euphrates and the Tigris and flow into the Persian Sea. This meant that the single Edenic river split outside the boundaries of Paradise: into the Euphrates and the Tigris in the North, and into the Pishon and Gihon in the South. ${ }^{78}$ Reland agreed with Huet that Scripture was referring to four separate bodies of water. He observed that each of the four bodies of water in the scriptural passage carried its own proper name. Although all of them originated from the same river in Eden, the branches became distinct, flowing rivers in their own right. ${ }^{79}$ Despite his agreement with Huet on the split into four distinct rivers, Reland's map of Paradise looked different from Huet's. According to the biblical text, the Pishon wound through the 'entire land of Havilah' [כל ארץ החוילה [כרי כ2] and the Gihon through the 'entire land of Cush' [כל ארץ כוש]. ${ }^{80}$ In regard to the former, Reland noted that this suggested a much lengthier course of the river than what Huet had proposed. ${ }^{81}$ Instead, Reland identified the Pishon as the River Phasis. Reland explained that one of the key criteria was size. Just like the Tigris and Euphrates, the Pishon and the Gihon must be larger bodies of water. Ancient authorities such as Strabo confirmed that the Phasis was a great river that sprang from a source in Armenia. ${ }^{82}$ With regard to the Gihon, Reland set his eyes on the Araxes River. The ancient writer Arrian had numbered the Araxes among the great rivers of Asia. Reland explained that there was some confusion among ancient writers about the name of the river. The scholia on Appollonius's Argonautica, for example, report that the River Thermodon was called by the same name as the river originating in Armenia. Ultimately, however, there was no question that the Pishon and the Gihon were to be identified as the Phasis and Araxes rivers, because their springs

78 Huet, Tractatus de situ paradisi terrestris, p. 29: '[...] \& non videre possit, quatuor fluvios, magnum Paradisi fluvium dividentes, a parte superiore Euphratem \& Tigrem extitisse; \& a parte inferiore due brachia, quae communem alveum Tigridis \& Euphratis dividunt, antequam in Sinum Persicum illabitur'.

79 Reland, 'Dissertatio de situ paradisi terrestris', p. 7: 'Erunt itaque ut emphasi verborum Mosis satis fiat Phison \& Gihon flumina ab ipso Euphrate \& Tigri distincta \& ex eodem cum iis loco profluentia a communi origine, fluvio Edenico'.

8o Gen. 2:11-13.

81 Reland, 'Dissertatio de situ paradisi terrestris', p. 13: 'At non est id flumen tantae magnitudinis (quod uno tantum gradui: e.15. milliaribus Germanicis ipse Illustris Huetius in tabula Geographica definit) ut terram Chavilae \& quidem emphatice כל ארץ החוילה universam terram Chavilae ambire possit dici'.

82 Ibid., p. 8: 'Et praeterea notari meretur ipsum Phasin a scriptoribus profanis diserte mag-

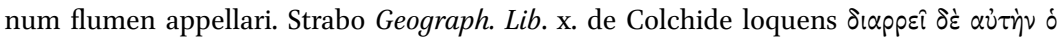

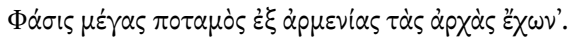


were in close proximity to those of the Tigris and Euphrates. ${ }^{83}$ In fact, Reland elaborates, Pliny reported that the Araxes had its source in the same mountain as the Euphrates, which Strabo called Mount Abus. ${ }^{84}$ Therefore, since the sources of all of these rivers were in Armenia, it was clear to Reland that this is where Paradise must have been located ${ }^{85}$ Reland's thesis about the Armenian origins of Paradise was not entirely new. Allusions to such a theory existed as early as the sixteenth century. ${ }^{86}$ Using references to Roman, Greek, Hebrew, Arabic and Persian sources, Reland's treatise was without a doubt the most detailed scholarly attempt at this point to situate Paradise in Armenia without worrying about an extant single river of origin. From the correspondence between Gisbert Cuper and Huet, we get the impression that the latter did not endorse Reland's theory-something which nonetheless had no effect on their cordial scholarly relationship. ${ }^{87}$ It is telling, however, that the Benedictine Dom Augustin Calmet (1672-1757), whose voluminous Commentaire littéral sur tous les livres de l'Ancien et du Nouveau Testament was published between 1707 and 1716, basically hijacked Reland's thesis without giving him any scholarly credit. ${ }^{88}$ Unfortunately, even modern scholars have somewhat uncritically credited Calmet rather than Reland with this contribution to the Early Modern quest for Paradise. ${ }^{89}$

But neither modern scholars nor their Early Modern predecessors could ignore Reland's magnum opus in the field of sacred geography. Even if he had not received deserved applause, his early treatises on the geographia sacra had placed Reland firmly on the map of scholarly explorers. He travelled through time and space to find Paradise in Armenia, tracked down the Israelites on their flight to the Red Sea, plowed through the Samaritans' story to 'climb' Mount

83 Ibid., pp. 32-33: 'Quemque Arrianus lib. vii. De exped. Alex. inter maximos Asiae fluvios recenset. Ut prohoc statuamus facit non tantum ipsa Systematis nostri ratio, quod fontes alicuius fluminis propriores fontibus Tigridis, Euphratis \& Phasidis nuspiam invenit, sed mira convenientia nominis גיחון cum Araxe'.

84 Ibid., p. 5o: 'Plinius lib. vi. c.9. ubi scripserat Armeniam fundere Euphratem \& Tigrin, pergit. Araxes eodem monte oritur quo Euphrates vi. mill. passuum intervallo. Strabo illum

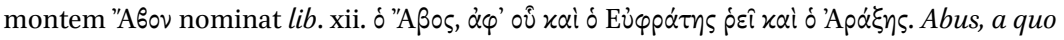
Euphrates fluit \& Araxes'.

85 Ibid., p. 4: 'Puto itaque in Armenia fuisse olim Paradisum terrestrem, \& eo quidem loco, qui medius est inter fontes quatuor fluviorum, Phasidis, Araxis, Tigridis \& Euphratis, quos esse illos credo qui a Mose describuntur nominibus Phisonis, Gihonis, Chiddekel, \& Phrath $[\ldots]$.

86 See Scafi, Mapping Paradise, pp. 317-320.

87 See Pélissier, 'Lettres inédites', pp. 65-66.

88 See Calmet, Commentaire littéral, pp. 59-76.

89 See Scafi, Mapping Paradise, pp. 321-322. 
Gerizim, and 'sailed' to Goa to find Salomon's mysterious Ophir. ${ }^{90}$ Reland's network and scholarly reputation yielded an audience eagerly awaiting his next work. ${ }^{91}$ In 1713, for instance, Gisbert Cuper informed Mathurin Veyssière de La Croze that the third and last book of Reland's Palaestina had been sent off to the press and that this 'excellent work' would be available soon. ${ }^{92}$ But the scholarly network did not just remain on the sidelines. It became an important asset and resource for Reland in the pursuit of completing his work. Five years before the work appeared in print, the Journal des Sçavans printed excerpts from a letter it had received from Reland. The journal announced that Reland's book on the geographia sacra would be 'much more precise and clear than those that had appeared until now, because it contained nothing that was not proven by authoritative evidence. ${ }^{93}$ Although these announcements in scholarly periodicals may have been important means to publicize a scholarly work, they also raised the bar of anticipation. Reland may have thrived under pressure, but it certainly took its toll. In spite of his excellent preparation and skill, the work was incredibly challenging, mentally draining, and physically exhausting. Reland apparently subordinated his entire daily routine to this project. He even moved to an estate outside of Utrecht to eliminate any unwanted distractions and find the peace and focus to work on his book. ${ }^{94}$ Peter Burman, one of Reland's colleagues at Utrecht, wrote in a letter to their mutual friend Antonio Magliabechi (1633-1714):

Our Reland has pressed on to elucidate his Geographia sacra with such vigour that he fell ill, which completely drained all of his physical strength; thus he was ordered by the doctors to abstain entirely from all literary contemplation; although some of his strength appears to have

9o These are all treatises in Reland's Dissertationum miscellanearum.

91 On 25 May 1711, for instance, Gijsbert Cuper wrote to La Croze: 'Les quatre Médailles Arabes sont entre mes mains, \& j'en ai envoyé une à Mr. Reland, qui travaille toujours à la Géographie Sainte [...]'. See Lettres de critique, p. 95.

92 ' $[. .$.$] le 3^{\text {me }}$. \& le dernier Livre de la Palestine de Mr. Reland est mis sous la presse, \& je crois, que nous aurons bientôt cet excellent Ouvrage; je parle ainsi parce que j'en ai vû des beaux échantillons'. See Cuper, Lettres de critique, pp. 127-128.

93 Supplément du Journal des Sçavans (3o September 1709), p. 658: 'M. Reland se propose de donner au public une Geographie de la Terre sainte beaucoup plus exacte \& plus certaine que celles qui ont paru jusqu'à présent: elle ne contiendra rien qui ne soit appuyé sur des autoritez'.

94 'Wir erinnern uns zur selben Zeit aus Briefen guter Freunde verstanden zu haben, wie der Verfasser über dieser seiner Arbeit so eifrig gewesen, daß er derselben auf einem Landgute unweit Utrecht obgelegen, um desto ungestörter zu bleiben'. See Deutsche Acta Eruditorum, vol. 31, p. 521. 
been restored, I am greatly worried that he does not want to comply with the warnings of his friends to take a break from this overly harsh and intense study routine. ${ }^{95}$

Burman's intellect and wit may have been extraordinary in matters of classical philology and scholarship, but apparently not so in practical matters of social and medical care. His plea with Magliabechi on behalf of his colleague Reland could hardly have been more misdirected. Although a kind soul who was always willing to help others in matters of scholarship, Magliabechi was the archetype of a scatterbrained academic, who neglected personal care and hygiene to a degree of self-endangerment. ${ }^{96}$ Fortunately, Burman's concern, at least at this point, must have been unwarranted; Reland was able to complete Palaestina illutrata without collapsing in the process. Reland's illness may have delayed the completion of his work, but it did not prevent it. ${ }^{97}$ And the work was everything he had promised and more! Although academic publications that are celebrated as the 'definitive treatment of anything' never really are, since they are all mere snippets of a scholarly world in motion, Reland's massive book was indeed a showcase of philological erudition and a treasure trove of information in the field of biblical scholarship. Its dense content elevated it into a league with the work of Bochart or Spanheim. The latter had published his Introductio ad geographiam sacram Patriarchalem, Israëliticam, \& Christianam in 1679. But with a mere 300 pages, Spanheim's work pales in comparison to Reland's massive two-volume tome of over 1,ooo pages.

In all fairness to Spanheim, he had a different readership in mind to that of Reland. Spanheim's work was explicitly meant to be used by the studiosa

95 'Relandus noster tanta contentione in Geographiam sacram illustrandam incubuit, ut in infirmitatem, quae omnes fere vires exhausit, incideret, ita ut a Medicis plane ab omni literarum meditatione abstinere iussus sit, \& licet paullum refectae iam vires videantur, timeo tamen ipsi male, nisi obtemperare amicorum monitis, \& a studio illo nimis acri \& vehementi animum remittere velit'. See Magliabechi, Clarorum Belgarum, p. 3oo; on Burman, see my 'The Scholar as Whoremonger'; also, Grafton, 'Spinoza's Hermeneutics', pp. 179-182.

96 See 'Magliabechi', in Grosses vollständiges Universal-Lexicon, p. 370: 'Er war sonstens von sehr schlechten äusserlichem Putz, und trug Winters-Zeit allemal ein Kohl-Feuer bey sich, woran er sich öfters die Kleider und Hände beschädigte, pflegte auch gemeinlich auf rohen Büchern, die er mit einer Madratze bedeckt, zu schlaffen'.

97 'Sie würde auch vermuthlich ehe an den Tag gekommen seyn, wenn nicht der Herr Verfasser mitlerweile in eine schwere Kranckheit gefallen wäre, die ihm vielleicht sein allzuvieles Studiren zugezogen, und von der er sich erst erholen müssen'. See Deutsche Acta Eruditorum, vol. 31, p. $5^{21}$. 
iuventus. It was a 'college textbook', so to speak. ${ }^{98}$ Reland's book, on the other hand, was much more ambitious. What started out as a commentary on Josephus became the first comprehensive attempt to create a topographic map of Palestine. ${ }^{99}$ Included in the book are eight detailed maps that show the location of mountains, rivers, lakes, and several key cities. Unlike his predecessors, Reland did not simply follow the established custom of copying some preexisting map, but had all maps redrawn on the basis of the information available to him. ${ }^{100}$ These, of course, were ancient sources, which he used to reassess distances between cities and places in order to enter them in Roman miles. ${ }^{101}$

For instance, adding up the distances between individual cities recorded in Josephus, Eusebius, and others, Reland arrived at a total distance of about 156 Roman miles from Dan in the north to Bersabee in the south of Palestine. ${ }^{102}$ Reland applied this same precision to both physical and cultural geography. A testimony to Reland's detail-oriented approach was his documentation of mountain ranges. Earlier maps of the Holy Land, including those in Bochart's and Spanheim's Geographia sacra, were imprecise when it came to such topographical detail. Reland's work, on the other hand, included one entire map dedicated solely to displaying mountain ranges. It is labeled 'Conspectus Libani atque Antilibani secundum observationes Henr. Maundrelli ex autographo eius descriptus' [Survey of the Lebanon and Anti-Lebanon Mountain according to the observations of Henry Maundrell, sketched from his autograph]. The map is based on the Levantine travels of the English clergyman Henry Maundrell (1665-1701), whose journals were published two years after his death in 1703. The purpose of Maundrell's trip from Aleppo to Jerusalem in 1697 was not solely spiritual, but also an attempt to provide an improved

98 Spanheim, Introductio ad geographiam sacram.

99 'Hadrianus Relandis Loca Geographica Josephi justo Commentario illustrare constituit'. See Acta Eruditorum, vol. 2, p. 272.

100 Reland, Palaestina, fol. * $3{ }^{r-}{ }^{*} 3 v$ : 'Nolui consuetudinem sequi quae increbuit, \& mappam aliquam vulgatam, cuiusmodicunque fuerit, correctam hic illic in conspectum hominum denuo proferre: sed quum mihi in univero hoc argumento nihil fuerit antiquius quam certe secernere ab incertis, omnes tabulas iuxta aestimare \& veluti dubias atque ambiguas negligere idoneum visum fuit, atque ab ipsis carceribus justo itinere viam illam conficere, quam ingrediendum est si quis feliciter in hoc stadio voluerit decurrere'; see Bartlett, Mapping Jordan, pp. 88-95.

101 Reland, Palaestina, fol. *3v.: 'Ex veterum itaque scriptis collegi quaecunque ad situm locorum \& intervalla facere videbantur; inprimis quae per miliaria Romana aut stadia, quae ad miliaria redegi, erant digesta; qualia multa extant in scriptis Josephi, Eusebii, Hieronymi, itinerariis Romanis, \& aliis monumentis: eaque tantum non omnia libro singulari, operis huius secundo, comprehendi'.

102 Ibid., p. 423: 'A Bersabee usque ad Hierosolymas sunt mil. 42. Ab Hierosolymis ad Bethel. Ex Itinerar. Veter. Hieros. \& Eusebio, mil. 12 [...]. Hic fiunt millaria Romana 156'. 
description of the geography of the area. ${ }^{103}$ The journals, however, did not include the map apparently sketched by Maundrell, but Reland was able to obtain the drawing through his contacts. ${ }^{104}$ Maundrell's notes in combination with classical sources helped Reland identify and chart the course of the Lebanon and Anti-Lebanon mountain ranges.

Reland traced the term 'Libanus' to the Hebrew לבן, 'to whiten'. But this may not necessarily be a reference to its snow-covered peaks. According to Reland, the term 'Libanon' could also be a reference to the Temple of Jerusalem. Jewish sages such as Yohanan ben Zakkai viewed the Temple as the place where the slaughter of sacrificial beasts atoned for the transgressions of the faithful. Alternatively, of course, it could also be a reference to the cedar trees that were brought in from Mount Lebanon during the construction process of the Temple. ${ }^{105}$ When it came to further identifying these mountain ranges, Reland was able to draw on a wealth of information from ancient writers. As usual, however, there was little agreement among them. Ancient evidence from coins suggested to him that the ancients sometimes utilized the term Lebanon when they were actually referring to the Anti-Lebanon range.

This, for instance, was the case with the cities of Hierapolis and Laodicea, which were both situated in the Anti-Lebanon mountains. ${ }^{106}$ Strabo placed Mount Lebanon in the North, above the sea near Tripolis, and the Anti-Lebanon above the sea near Sidon further to the south. Both mountain ranges were separated by a large valley of about 400 stadia. ${ }^{107}$ But some of the geographical

103 Butler, 'Maundrell'; see also Matar, 'The Sufi and the Chaplain', pp. 164-184.

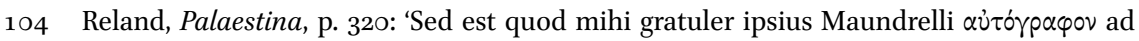
manus meas pervenisse, in quo \& Libani situm atque Antilibani locorumque vicinorum descripsit'.

105 Ibid., pp. 312-313: 'Libani quod a לבן duximus. Inde intelligimus quamobrem in scriptis Prophetarum nomen Libani tribuatur Templo. Non ignoravit hoc vir clarus inter suos, Rabban Jochanan Ben Zaccai, qui quum apertas sponte templi fores conspiceret [...] praesagiebat non longe abfore tempus quo aedes sacra conflagraret, exclamans, Aperi, o Libanon, portas tuas ut consumat ignis cedros tuas. Si rationem Judaeos roges, quamobrem templum Libanus dicatur, respondebunt quia oblatione victimarum in Templo peccata expiabantur [...]. Posset quoque dici, ob eximiam copiam cedrorum ex Libano petitarum ad constructionem templi, locum hunc regione ubi ligni caeteroquin magna erat penuria veluti alterum Libanum extitisse'.

106 Ibid., pp. 311-312: 'Adde \& ipsos veteres Antilibano nomen Libani tribuisse. Extant nummi cum epigraphe IEPAПO $\Lambda$ EIT $\Omega N$ EN T $\Omega \Lambda$ IBAN $\Omega \& \Lambda$ AO $\Delta$ IKE $\Omega N$ ПPO $\Sigma T \Omega \Lambda$ IBAN $\Omega$ vel EN T $\Omega \Lambda$ IBAN $\Omega$. Erant tamen hae urbes Antilibani'.

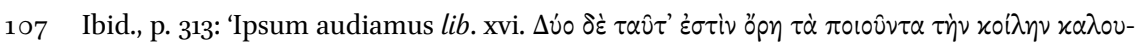

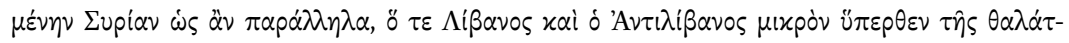

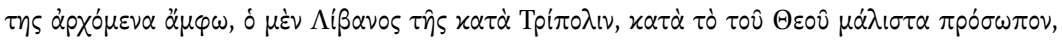

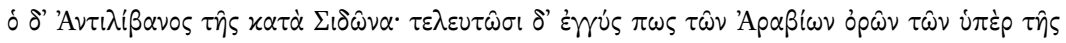


markers in Strabo and other ancient writers such as Procopius complicated matters for Reland. They seemed to suggest that the Lebanon mountains extended as far as the Euphrates river. Reland, of course, thought that this was absurd. ${ }^{108}$

More useful to Reland was the information he gathered from Josephus. The Jewish historian located the city of Dan not far from Mount Lebanon, near the springs of the Lesser Jordan River. Dan was twenty Roman miles from Tyre and a day's journey from Sidon. ${ }^{109}$ But where the information of ancient writers did not satisfy him, Reland was able to draw on more recent accounts. The medieval geographer Marino Sanuto the Elder (126o-1338) reported that Mount Lebanon was never more than two leagues from the sea, except in the area of Tripoli, where the distance between the Mediterranean and the mountain range was three leagues. With the aid of Maundrell's journal and the sketched map, Reland was able to shed further light on the course of these two mountain ranges. He concluded that Mount Lebanon must run parallel to the coastline of the Mediterranean and was separated from the Ani-Lebanon mountain range in the east by a substantial valley, as Strabo had noted. This was confirmed by Maundrell's description of the group's journey east from Sidon on the Mediterranean to Damascus, which lead them across both the Lebanon and Anti-Lebanon mountain ranges. ${ }^{110}$

In spite of their disagreements over exact locations, it would have been hard for ancient and Early Modern writers to ignore massive landforms such as mountain ranges or lakes. Other physical characteristics of a region, however, were much easier to miss. Fluvial systems were a case in point. The course of the Jordan was, of course, well-documented, but other rivers and streams were much harder to locate, especially when the language was ambiguous.

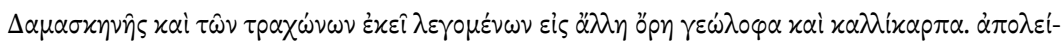

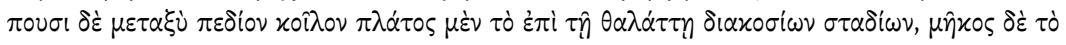

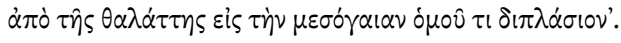

108 Ibid., p. 316: 'Quis non videt hanc Chalcidem ab alia superiore longe esse diversam? Nisi velimus Libanum porrigere usque ad viciniam Euphratis, quod absurdum est'.

109 Ibid., p. 316: 'Urbem Dan ille non longe a Libano \& fontibus Jordanis minoris conditam scribit Antiq. v.2. aberat autem haec Tyro 20 mill. \& a Sidone itinere unius diei quod alibi ostendimus'.

110 Ibid., p. 319: 'Unum ex scritoribus nostrorum temporum addam Henricum Maundrellum, qui Libani atque Antilibani situm accurate describit; sic ut Libanus iuxta litus maris (Sanutus in secretis fidelium crucis pag. 155. tradit nusque Libanum a mari recedere per duas leucas nisi iuxta Tripolin, ubi per 3 leucas distat: interdum tamen ita accedere ad mare ut nulla relinquatur via) se extendat ab austro versus septentrionem: Antilibanus similiter ad austro septentrionem versus procurrat valle intermedia a Libano secretus, \& Damasco sive plagae orientali vicinior'. 
Based on their location, Reland divided Palestinian streams into those in the Transjordan and Cisjordan regions. Depending on their size, Reland explained, ancient writers may have used alternative expressions to refer to fluvial systems. For a smaller stream, Greek authors were more likely to use the term

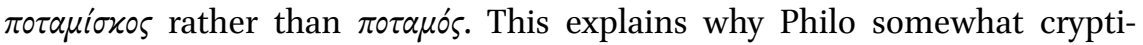
cally observed that there were no rivers anywhere near Jerusalem, although the Kedron ran right by it. Similarly, the Hebrew term נחל can mean 'a valley' or 'a brook', because small streams dry up and become valleys without water. The Greeks called these seasonal winter-swollen streams $\chi \varepsilon^{\prime} \dot{\mu} \mu a p \rho o{ }^{111}$ Reland's sources revealed several examples of these bodies of water that were not found easily on maps. This means there may be bodies of water where no one had suspected. One example comes from Scripture, where Psalm 126:4 mentions streams in the Negev [כאפיקים בנגב], in the Cisjordan region, in the south of the Holy Land. According to Reland, Strabo cited Eratosthenes who reported that there were underwater streams that surfaced in the area around Rhinocolura and Mt. Cassius. Further confirmation came from Joshua in the Bible, which mentions 'the brook of Egypt' [נחל מצרים], flowing near Rhinocolura, as the southern boundary of Judah. ${ }^{112}$ Reland argued that the course of this stream must have been east of the city, because Jerome situated it between Pelusium and Rhinocolura. Misleadingly, it could be taken as a reference to the Nile, because, as stated in 1 Chron. 13:5, 'David assembled all Israelites from the Schichor River in Egypt'.113 But despite the name 'brook of Egypt', this elusive stream could under no circumstances be a reference to the Nile. Reland explained:

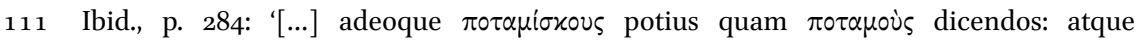
Hierosolyma longe a $\pi \circ \tau \alpha \mu o i \zeta s$ sita scribit Philo de somniis, quum tamen in proximo esset torrens Kedron. At is $\pi \circ \tau \alpha \mu \circ \hat{~ n o m e n ~ h a u d ~ m e r e t u r . ~ D e i n d e ~ n o m e n ~ נ ח ל י ם ~ v a l l e s ~ a e q u e ~ a c ~}$ flumina notare, \& saepe numero incertum esse, quando נחל aliquis memoratur in Sacro Codice, debeatne vallis an flumen intelligi: quumque multa flumina ex his torrentia sint, \& aestate exsiccata alveum suum uti vallem ostendant, quemadmodum \& Ovidius lib. 11. Metamorphoseon septem brachia fluvii exsiccata appellat septem sine flumine valles, potest ea vox נחל \& flumini \& valli adaptari. Graeci vocem נחל per pexppov reddere solent, id est, torrentem sive hybernum flumen'.

112 Jos. 15:4.

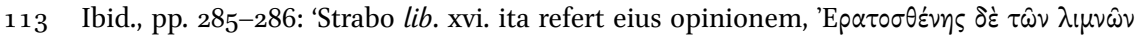

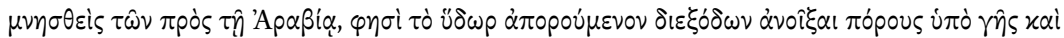

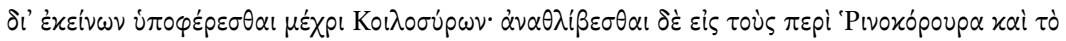

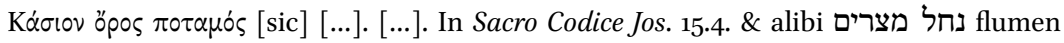
Aegypti appellatur illud quod Rhinocolura alluit. Erat autem ad austrum urbis, quia Hieronymus illud labi testatur inter Pelusium \& Rhinocolura. De ratione huius nomiשis disquiri solet, unde ductum sit, \& an non ipse Nilus intelligi debeat, quoniam שיחור Schichor, \& Schichor Aegypti appellatur 1 Chron. 13.5' 
Since at the time of Joshua Egypt did not extend as far as to where Rhinocolura was built later, it appears clear that the river flowing near Rhinocolura was not called 'stream of Egypt' as if it was in Egypt but that epithet 'of Egypt' refers to something else. ${ }^{114}$

Besides, Egypt did not even share a border with Israel. In the first twentysix chapters of his book Reland had established the historical boundaries of Palestine, partly also by including regions and population groups with which it shared borders. Although Cyril of Alexandria noted that the Egyptians shared a border with the Canaanites, Reland judged the passage unreliable as a source. The Greek text stated that the Euphrates marked the southern border of Palestine, which suggested to Reland that a verb was missing and the passage was corrupt, because the Euphrates was nowhere near that location. ${ }^{115}$ Instead, it seemed very clear that Palestine shared a border with the Philistines in the south. Reland explained that the Philistines traced their origins to the Cashluhites who came originally from the region of Capthor, which appeared to have been on the Egyptian coast near Pelusium. ${ }^{116}$ Later, ancient Greek

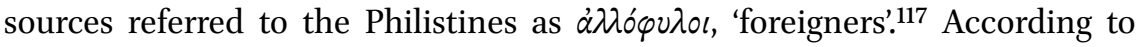
Exodus 13:17-18, God instructed the fleeing Israelites to take a detour rather than the direct route through the land of the Philistines [דרך ארץ פלשתים].118 Accordingly, the Philistines must have occupied the coastal area along the

114 Ibid., p. 286: 'Quum porro Aegyptus ipsa tempore Josuae se non extenderit usque ad illum locum ubi Rhinocolura postea condita sunt, clarum videtur non posse flumen Rhinocolura alluens fluvium Aegypti dici ac si in Aegypto esset, sed alio referri oportere illud epitheton Aegypti'.

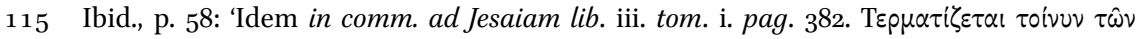

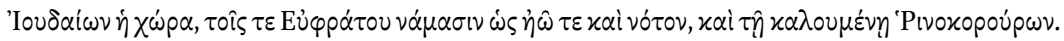

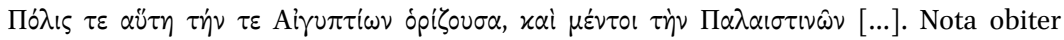
locum esse mendosum: scribendum enim fuerat, nec hoc ignorare potuit Cyrillus, ipse Archiepiscopus Alexandrinus, ad austrum esse Rhinocorura teminum Palaestinae, \&

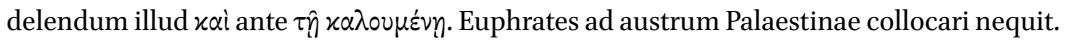
Res notior est quam ut verbum addere necesse sit'.

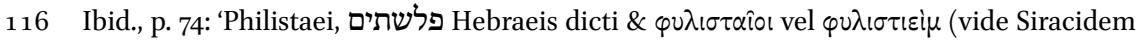
cap. 46.21. \& 1 Macc. 3.24.) originem traxerunt a Casluchaeis, qui patrem habuere Mitzraim Gen. 10. Profecti sunt e regione Caphtor, כפתר, Amos. 9.7. Deut. 2.23. quae videtur in ora maritima Aegypti circa Pelusium quaerenda'.

117 Ibid., p. 75: 'Deinde Philistaei dicti sunt $\alpha \lambda \lambda_{0} \varphi \varphi \lambda{ }_{0}$, quasi extrarii, \& regio eorum $\gamma \hat{\eta}$

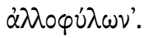

118 Ibid., p. 77: 'Nam Exod. 13.17,18. opponuntur viae duae, quibus ex Aegypto ad terram Canaan iter esset, altera דרך ארץ פלשתים via per terram Philisaeorum, qua Deus popo-

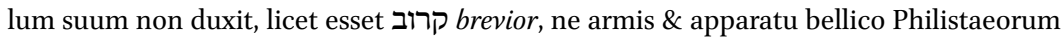
territus reverteretur in Aegyptum [...]'. 
Mediterranean between Egypt and Canaan. Since the Philistines are not mentioned in the conquest narrative, they could not have inhabited Palestine proper during the time of Joshua. This, however, changed. Later, the cities of

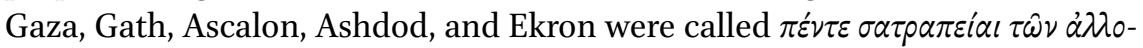
$\varphi v \dot{\lambda} \omega \nu$, 'five satrapies of foreigners', which suggests that parts of Palestine were from time to time under Philistine occupation.

Given that Palestine did not share a border with Egypt and Rhinocolura was on Palestinian soil, where was this mysterious 'brook of Egypt' [נחל מצרים] located? Reland found a solution to the problem in Scripture. In Joshua 13:3, Schichor is described as the river 'that faces Egypt' [שיחר אשר על פני מצרים]. Reland concluded that the Hebrew term 'Egypt' [מצרים] referred to the stream's direction and did not at all mean that it was a river in Egypt. It 'turned towards Egypt' or was near the Egyptian border, just as the biblical 'Almon Diblathaim' should be translated as 'Almon near Diblathaim..119 We can almost visualize Reland at work; consulting every possible classical writer, looking at existing maps, puzzling over philological terminology, corresponding with his network about intricacies of the text and access to information.

Admittedly, some of Reland's arguments were far-fetched and did not even convince his contemporaries. Reland's successor at Utrecht, the Hebraist David Mill (1692-1756) for instance, was unwilling to abandon the idea that the Schichor [שיחר] was a reference to the Nile in Egypt, and so were others. ${ }^{120}$ But hardly any Early Modern biblical scholar, philologist, or theologian was able to ignore or fail to acknowledge the monumental contribution of Reland's Palaestina illustrata. It elevated the study of biblical geography onto a new plane. Even the notoriously critical savant Jean Le Clerc, who used his pen to reduce the work of many of the giants of the Republic of Letters to mere rubble, graced Reland's work with an exceptionally elaborate and positive review. ${ }^{121}$ According to Le Clerc, 'nobody before made such an effort in this subject matter as Mr. Reland', who examined the whole body of 'Hebrew, Arabic, Greek, Latin sources', along with records from ancient and modern travellers' in order

\footnotetext{
119 Ibid., pp. 286-287: 'Aetate Josuae Aegyptus eo usque se non extendit \& inter illam ac terram Israeliticam erat intermedia regio Philistaeorum [...].Jos. 13. 3. flumen hoc appellatur Schichor qui est ante faciem Aegypti. Hic discimus idem esse flumen Aegypti quod flumen respiciens Aegyptum [...]. Erit ergo Schichor, vel flumen Aegypti id flumen quod Aegyptum respicit vel Aegypto, vicinum, uti Almon Diblathaim creditur esse Almon prope Diblathaim [...]'.

120 Mill, Dissertationes selectae, pp. 1-30.

121 Le Clerc, Bibliotheque, pp. 36o-408.
} 
to provide 'numerous clarifications' of locations and places of previously unclear provenance. ${ }^{122}$

If the Palaestina cemented Reland's reputation as one of the foremost biblical scholars of his age, his influence as a teacher was certainly no less profound. Reland's commitment to teaching becomes clear just by simply looking at a number of his publications. Many of them were geared toward a student audience. They include his Analecta rabbinica (1702) [Rabbinical Excerpts] and his Elenchus philologicus (1706) [Philological Cross-Examination], which were all designated as in usum studiosae iuventutis [for the use of students].123 This does not, of course, diminish their value, but it highlights the pedagogical side of Reland's 'Orientalism' and scholarship. In fact one could argue that his influence as an educator in the field of Christian Hebraism may have been even more pervasive and lasting than his scholarly legacy. Reland wrote what would be the seminal textbook for the study of Jewish antiquities for decades to come. The nineteenth-century English theologian and bibliographer Thomas Hartwell Horne (1780-1862), author of the immensely popular Introduction to the Critical Study and Knowledge of the Holy Scriptures, referred to Reland's Antiquitates sacrae veterum Hebraeorum as the 'textbook of professors'. ${ }^{124}$

The reason for the enduring and pervasive influence of Reland's book was certainly not due to a lack of material on the market. Quite the contrary was the case. As we have pointed out earlier, the seventeenth century in particular could be called the 'heyday of Christian Hebraism'. The market was virtually flooded with books on every aspect of the antiquitates sacrae. The most impressive testimony of the amazing prolificity of the Christian Hebraism of the period are the thirty-four mighty tomes of Blasius Ugolini's Thesaurus antiquitatum sacrarum (Venice, 1744-1769), which cover virtually every aspect of ancient Jewish culture. The roots for this interest were manifold. They range from political idealizations of the commonwealth of the Hebrews to a curiosity about 'exotic cultures', triggered by the age of discovery.125 What matters in our case, however, is the emphasis Protestant savants mainly placed on the study of ancient Jewish rituals and customs as a key element of their

122 Ibid., p. 368: 'Il a fouillé, dans tous les monuments Hebreux, Arabes, Grecs, Latins, \& dans les Voyageurs anciens \& modernes, ou il a pu trouver quelque éclaircissement; \& je croi en effet que personne ne s'est tant donné de peine, sur cetter matiere, que M. Reland'.

123 Reland, Elenchus philologicus; idem, Analecta rabbinica.

124 Horne, Introduction, p. 727, referring to the abridged edition:'Hadriani Relandi Antiquitates sacrae veterum Hebraeorum recensuit, et animadversionibus Ugolinianis-Ravianis auxit, Georgius Joannes Ludovicus Vogel . 8vo. Halae, 1769. The best edition of a valuable little summary, which for many years continued to be the text-book of professors'.

125 Nelson, Hebrew Republic; Stroumsa, A New Science, p. 71. 
hermeneutica sacra. ${ }^{126}$ Terminological lines between the concepts of philologia sacra and hermeneutica sacra were much less pronounced than today. Salomon Glassius divided his Philologia Sacra into the categories philologia, grammatica, rhetorica sacra, and logica sacra. Under the category philologia, he covered the twofold sense of scripture, namely sensus literalis and the sensus mysticus. ${ }^{127}$ Similarly, the Christian Hebraist August Pfeiffer (1640-1698) from Lübeck included the section De sensu Scripturae Sacrae in his celebrated Hermeneutica Sacra (1684), as did Johann Jacob Rambach (1693-1735) a few decades later in his widely influential Institutiones hermeneuticae sacrae $\left(175^{2}\right) .{ }^{128}$ Both Pfeiffer and Rambach include in their work a section on proper tools of interpretation. Under the section De mediis hermeneuticae sacrae both authors included not only grammatical exegetical tools but also auxiliary disciplines such as history, chronology, geography, and rabbinic sources. According to Rambach, an understanding of the rituals and antiquities of the Jews was vital for an understanding of both Testaments, especially with regard to typology. Many passages in the Old Testament would hardly make sense unless they were put into the context of Jewish antiquities. Even more importantly, a lack of understanding of ancient Jewish ritual law would be detrimental to a proper understanding of the New Testament.

Already Louis Cappel had, according to Rambach, emphasized that there were 'many passages in the New Testament, in which both Christ and the Apostles turned their thoughts to the ideas, proverbial expressions, parables, pithy sayings, customs, and principles of the ancient Jews of their time, among whom they lived and taught'. ${ }^{129}$ For instance, Jesus' parable in Matt. 21:44 must be viewed against the background of ancient Jewish laws of capital punishment by stoning, outlined in the Talmudic tractate Sanhedrin. ${ }^{130}$ This example

126 Van Miert, Emancipation, pp. xiii-xxiii.

127 Glassius, Philologia sacra, p. 347: 'Scripturae sacrosanctae sensus duplex esse: Literalis \& spiritualis seu mysticus'.

128 Steiger, 'The Development of the Reformation Legacy', pp. 740-743.

129 Rambach, Institutiones, pp. 535-536: 'Praecipuum vero usum praestant, qui ritus et antiquitates suae gentis descripserunt; quarum cognitio quam plurimis utriusque testamenti locis lucem adspergit, \& typologiam sacram quodammodo adiuvat. Multa veteris testamenti loca difficilia esse intellectu, nisi peritia antiquitatum ebraicarum instructus, ad illa accesseris, experientia docet [...]. Multa enim sunt in N.T. in quibus tum Christus, tum eius apostoli respexerunt ad sententias, proverbia, parabolas, gnomas, mores, dogmata veterum sui temporis Iudaeorum, inter quos vixerunt \& docuerunt [...]; ut monet LUD. CAPPELLUS, in praefat. Spicilegii sui'.

130 Ibid., p. 537: 'Verba Matth. XXI,44. Qui in eum lapidem ceciderit, confringetur; \& in quem lapis inciderit, eum conteret: ex ritu lapidationis, apud Iudaeos recepto, explicanda sunt, de quo Sanhedrin c. VI. Locus lapidationis altitudine aequavit duplicem hominis staturam: 
illustrates how vital a knowledge of the Talmud and Mishna was not only for the study of the Old Testament but for the New Testament as well. The English Hebraist and minister John Lightfoot (1602-1675) meticulously compiled these kinds of references to the Talmud in the New Testament in his massive sixvolume Horae hebraicae et talmudicae (1658-1678). When John the Baptist, for instance, refers to the Pharisees and Sadducees as 'generations of vipers', Lightfoot supplied an elaborate cultural and linguistic discussion of the terms Pharisee and Sadducees. Providing ample references from the rabbinic corpus, Lightfoot noted, for instance, that the doctrine of the denial of the resurrection must have existed some time before the Sadducees entered the scene. ${ }^{131}$

References to ancient Jewish practices, such as the example about execution by stoning, generated a massive body of scholarly works. These were the kind of topics debated in disputations at universities and throughout the 'Republic of Christian Hebraism' during the seventeenth and eighteenth centuries. A casual glance into Johann Albert Fabricius's Bibliographia antiquaria (1713), one of the standard reference publications for the studies of Greek, Roman, Hebrew, and Christian antiquities, reveals a section on poenae apud Hebraeos (punishment among the Hebrews). Fabricius briefly explained that there were four execution methods practiced in ancient Judaism, namely death by burning, stoning, strangulation, and decapitation. ${ }^{132}$ Besides references to Surenhusius's edition of the Mishna, Fabricius then lists dozens of references to books and treatises written by Christian Hebraists on capital punishment. They include references to Calmet or Johannes Leusden (1624-1699), as well as to lesser known scholars and their work such as Johann Ernst Bornitz's De מיתות seu suppliciis capitalibus Ebraeorum (1643), Christoph Borstorf's Dissertatio de poenis capitalibus Hebraeorum (1696) or Friedrich Siegfried Ring's De lapidatione Hebraeorum (1716). Although Fabricius's main goal was to compile as thoroughly as possible all publications about the death penalty in ancient Israel, his inclusion of works on the martyrdom of St. Stephen highlights how the study of Jewish antiquities was seen as avital component of doctrinal training and education. ${ }^{133}$

inde e clivo eum in terram praecipitavit unus e testibus, in lumbos impactum. Si inde moriebatur; bene; sin minus, testis alter lapidem in cor eius impingit'.

131 Lightfoot, Horae, p. 59: 'Sadducaeos ergo haereticos a Zadok denominatos on est inficiandum, at Sadducaeorum haeresim de Resurrectione antiquiorem nomine isto fuisse, non sine ratione opineris $[\ldots]$ '.

132 Fabricius, Bibliographia antiquaria, p. 747: 'Apud Hebraeos quatuor in usu fuisse suppliciorum capitalium genera feruntur, vivicrematio, lapidatio, strangulatio et poena gladii, quam putabant esse turpissimam'.

133 Ibid., pp. 747-749. 
Not surprisingly, Christian Hebraism became one of the greatest advocates and vehicles of the study of the antiquitates sacrae. Professorships of Biblical Antiquities existed at virtually every major university, including Utrecht, of course. Closely tied to the study of 'Oriental' languages, the subject matter basically included everything that pertained to the study of ancient Judaism. The Hebraist Johann Heinrich Hottinger (1681-1750), grandson of the great Swiss Arabist and theologian, and like Reland a protégé of Willem Surenhusius, provided the following 'job description' for prospective candidates:

Broadly, under the name 'Jewish Antiquities' fall all those records of the ancient Jews, which faithfully bequeath the origin of this people, its progress, its language, books, beliefs, customs, its rituals, both sacred and human, its places, calculations of time, offices, and so forth, for the purpose of an easier and clearer understanding of both Old and New Testaments. ${ }^{134}$

While Hottinger's description of the discipline makes perfect sense, the practical implications are clear. As the example of capital punishments in ancient Judaism may have suggested, this was a herculean task. We are talking here about a massive case of 'information overload' with no simple cure in sight. ${ }^{135}$ There were entire books on major subjects such as Johann Braunius's seminal work on Hebrew priestly garments or Johann Saubertus's book on sacrifices, not to mention the flood of smaller dissertations on even the smallest detail of ancient Judaism. ${ }^{136}$

How can all of the information about ancient Judaism along with its theological implications be packaged succinctly into the format of a monograph? Moreover, the challenge was to condense this information into a format that was digestible to students, but was still mindful of scholarly subtleties. One way of looking at this might be the attempt to write a world history textbook for undergraduate students today. Granted, the audience would be a lot less specialized and much broader, but the author would be faced with similar challenges with regard to the massive amount of material that needed to be covered. But whereas a team of authors is generally recruited by publishers

\footnotetext{
134 Hottinger, 'ЕІ $\Sigma \mathrm{A} \Omega \Gamma \mathrm{H}$ ', fol. Aıv: 'Late Antiquitatum Judaicarum nomine veniunt, omnia Veterum Judaeorum monumenta, quae Gentis illius origine, progressum, linguam, libros, dogmata, mores, ritus , tam Divinos quam humanos, loca, tempora, magistratus \& si quae aliae, fideliter tradunt, ad utrumque Codicem Veteris \& N. Testamenti facilius \& clarius assequendum'; see 'Hottinger', in Forsetzung und Ergänzungen, cols. 2157-2158.

135 See Blair, Too Much To Know.

136 Braunius, בגדי כהנים id est; Saubertus, De sacrificiis.
} 
today to work on a textbook project, the task to brave the flood of information and compile a textbook on the 'cultural history' of ancient Israel fell to courageous individual scholars. And some dared to venture into that territory, although with limited goals and success. The work by the Genevan Hebraist Bonaventure Corneille Bertram (1531-1594) is quite short and focuses strictly on the political and ecclesiastical governing bodies of ancient Judaism. ${ }^{137}$ More substantial was Carlo Sigonio's De republica Hebraeorum libri III (1582). The Roman Catholic Sigonio divided his book into seven chapters, focusing on the political and civil, and religious structure of the ancient Hebrew state. Apart from the fact that Sigonio's agenda was mostly political, as more recent scholarship has demonstrated, he was not a Hebraist and drew most of his information from the Vulgate, Philo, Josephus, and the church fathers. 138

Among the first comprehensive works by a Christian Hebraist was Petrus Cunaeus's (1586-1638) learned work published under the same title as Sigonio's. Unlike Sigonio, the Dutchman Cunaeus was an expert Hebraist, well acquainted with the rabbinic corpus and amply utilizing it to advocate ancient Israel as the perfect republican model. ${ }^{139}$ We can already see that many of these works were hardly suitable for the education of future generations of Hebraists, theologians, and ministers. Thomas Goodwin's much less idealistic Moses and Aaron: Civil and Ecclesiastical Rites used by the ancient Hebrews (1614), however, was indeed suitable. ${ }^{140}$ The book went through numerous editions in English and was published in Latin in Bremen in 1679 and in Utrecht in 169o. A Dutch translation of it appeared in 1694, along with a foreword by Hermann Witsius (1636-1708), one of Reland's teacher's when he was a student in Utrecht. ${ }^{141}$ It was reissued again in a Latin edition with scholarly notes by the younger Hottinger, 'the grandson' in 1710. ${ }^{142}$

137 See Bertram, De politia iudaica. The scholarship on 'political Hebraism' is massive and not a focus of this article. See, above all, Nelson's The Hebrew Republic and the very good introductory, albeit slightly dated, article by Neuman, 'Political Hebraism'.

138 Sigonio, De republica Hebraeorum. On the 'Hebraist' Sigonio, see Guido Bartolucci, La repubblica ebraica; also Bartolucci's article, 'Carlo Sigonio and the "Respublica Hebraeorum"'.

139 Cunaeus, De republica Hebraeorum. On Cunaeus, see Ziskind, 'Petrus Cunaeus'; also, Katchen, Christian Hebraists, pp. 37-55; Laplanche, 'Christian Erudition'; Nelson, Hebrew Republic, pp. 74-78.

140 Goodwin, Moses and Aaron; idem, Moses et Aaron.

141 Serrurier, Oratio funebris, p. 16: 'In eadem quoque caelestis sapientiae disciplina operam dedit Celeberrimis ea tempestate in hac Academia Viris, Gerardo van Mastricht, Hermanno Witzio, \& Hermanno van Halen'.

142 Fabricius, Bibligraphia antiquaria, p. 15: 'Anglica lingua Thomas Goodwin in Moses et Aaron, sive de ritibus et antiquitatibus hebraicis, qui ex vernacula saepius editus, hinc 
It would be interesting to know what motivated Reland to write his Antiquitates sacrae. Inspiration may have come from his own teacher Leydecker, who published a rather substantial volume under the title De republica Hebraeorum libri XII in 1704, four years before Reland's book appeared in print. ${ }^{143}$ But, just like Sigonio and Cunaeus, Leydecker's focus was predominantly on the ancient Hebrew theocracy. Leydecker's book may provide some clues. In his preface, Leydecker seems to classify Goodwin's Moses et Aaron mainly as a textbook. ${ }^{144}$ We know that Witsius used Goodwin's book in class, at least once he was at Leiden, and it would be intriguing to imagine Reland taking a class under Witsius on the antiquitates sacrae in Utrecht. ${ }^{145}$ One reviewer in the Journal des Sçavans notes the similarity in the layout of both Goodwin's and Reland's books. ${ }^{146}$ It is very likely that Reland's textbook was based on his own lecture notes. This was, in fact, not at all uncommon at the time. For instance, Fabricius's Bibliographia antiquaria was based on lectures of his own which he delivered at the Gymnasium illustre in Hamburg. ${ }^{147}$ We are left guessing here, because Reland did not add a preface to the work.

We know, of course, that Reland was in full agreement with his Christian Hebraist peers about the tremendous importance of the subject matter. It is no exaggeration to say that Reland viewed the study of Jewish antiquities as part of the process of knowing Christ. At the time when he was formally appointed to the professorship of sacred antiquities in 1713, Reland made this clear when

Belgice quoque, Daniele Peenio interprete, recusus apud Batavos Amstelod. 1694. 8. et latine cum notis brevibus Io. Henrici Reitzii, Bremae 1679 et sexta vice ibid. 1722.8 . cum novis eiusdem editoris animadversionibus et Herm. Witsius dissertat. duplici de theocraia Israelitica Rechabitis.Cum clarissimi Ioan. Henrici Hottingeri Nepotis, notis et animadversiones prima vice Francof. ad Moen. 1710 [...]'.

143 Leydecker, De republica Hebraeorum.

144 Ibid, 'Ad lectorem praefatio', n.p: 'Et postulata quoque sunt ab Academica Juventute Collegia ad Cunaeum \& Goodwinum, non neganda petentibus'.

145 See Jennings, Jewish Antiquities, p. ix: 'This piece of Godwin, stiled Moses and Aaron, the method of which our author chose to follow, hath been annoted and commented upon by a variety of authors [...]. There are two sets of annotations in manuscript, one by the learned Witsius, which he read to his students in the university of Leyden'.

146 Journal Des Sçavans (December 1746), p. 723: 'Le Moyse \& l'Aaron de Goodwin, n'est proprement qu'un Recueil de tous les Monuments qui concernent la République des Hébreux; ce Livre est rédigé à peu près dans le même ordre que les Antiquités sacrées de Relands [...]'.

147 Fabricius, Bibliographia antiquaria, fol. * 3 r: 'Bibliographia haec privatarum more paelectionum primum a me tradita, totaque consecrata fuit progressibus et captui studiosorum Iuvenum, frequentantium Gymnasium huius Urbis, quod hoc ipso anno 1713 bonis ut voveo speroque auspiciis celebrabit primum suum Iubilaeum, sive memoriam saecularem Musei huius publicaeque virtutum, pietatis et bonarum litterarum officinae, Optimorum Patrum cura ante hos centum annos conditae atque dedicatae'. 
he mounted the lectern on 11 February that year to address his audience. In his inaugural 'Address on the Value of Sacred Antiquities', Reland emphasized the responsibility the study of Scripture as a divine gift imposed upon both scholar and student. The study of these monuments provided, according to Reland, the key to unlock the mystery behind the powerful sacred words. ${ }^{148}$ In this regard, Reland's work fits perfectly into the long tradition of the philologia sacra outlined above. Coupled with his membership of a missionary society, which he joined in 1713, the purpose of Reland's scholarship was conservative from a theological point of view-Reland was committed to advancing the gospel.

Just as Goodwin had organized his Moses seu Aaron topically, so does Reland, but with some modifications. Reland's Antiquitates sacrae are divided into four sections: de locis sacris [about sacred places], de personis sacris [about sacred persons], de rebus sacris [about sacred matters], and de temporibus sacris [about sacred times]. He overlaps here with Goodwin, whose book consisted of the parts personis [of persons], locis [of places], diebus \& temporibus [of days and times]. But Goodwin also included the parts idolatria [of idolatry], consistoriis seu confessibus [of consistories and confessions], and ritibus mixtis [of mixed rites]. The first part of his Antiquitates, 'about sacred places', is at least in part Reland's home turf. Although his Palaestina was, at best, a work in progress when he completed his Antiquitates, we have seen that Reland's interest in the geographia sacra was a permanent fixture throughout his scholarly career. In his textbook he moves from the macro to the micro perspective, delineating first the boundaries of ancient Palestine, then moving to ancient Jerusalem, its temple, all the way into the Holy of Holies. The first chapter provides a brief treatment of Canaan's topography, including the 'river of Egypt' [נחל מצרים] in the south, as well as mountain ranges such as the Lebanon and Anti-Lebanon Mountains. What Reland would cover in close to four hundred densely-packed annotated pages in his Palaestina he condensed in his Antiquitates to seven meager pages. ${ }^{149}$ It is more or less a lecture outline, with hardly any scholarly references. Most of the references come from the Old and New Testaments, Josephus, and rabbinic sources.

\footnotetext{
148 Reland, Oratio De usu antiquitatum sacrarum, p. 7: 'Sacer codex coeleste donum est, \& inter illa quae Dei concessu atque munere generi humano tributa sunt, longe praecipuum [...]. Quis ergo dubitet quin omnia ad elucidandam vim verborum \& investigandum sensum qui in sacris his tabulis latet conferre oporteat? Quid jucundius, quam inoffenso pede in evolvendis illis monumentis pergere posse quibus ea docemur quae omnes reliqui mortales ignorant?'

149 Reland, Antiquitates, pp. 1-7.
} 
David Ruderman once observed that Reland's former mentor, the Hebraist Willem Surenhusius, viewed the Mishna as ever more closely approaching the New Testament as a source of revelation. ${ }^{150}$ We do not know exactly if, or to what extent, Reland may have been influenced by Surenhusius. But in his inaugural address, Reland dismissed 'potential Judaizing' charges as the spirit of bygone ages, when 'those who devoted themselves to the Hebrew writings were believed to take the side of the Jews'. ${ }^{151}$ Reland would certainly not go as far as to view the rabbinic corpus as an avenue to salvation, as Ruderman would like us to believe was the case with Surenhusius. But he saw the writings of Jewish sages as a key tool to find Christian truth in both Old and New Testaments. ${ }^{152}$ It may be premature to call Reland a 'philosemite', given the implications of the term. ${ }^{153}$ But comparing Reland's work with textbooks of the same genre such as Conrad Iken's Antiquitates Hebraicae (1732) shows that Reland was utilizing rabbinic sources to a much greater extent than Iken. This did not go unnoticed by his intellectual peers at the time. ${ }^{154}$ At no point when he referenced rabbinic material, did Reland dismiss them as fabulous or inferior. Reland consulted rabbinic sources whenever the account in Scripture was scanty, as was the case with his description of the inner sanctuary of the temple. According to Scripture, the ark was made of acacia wood, measuring $2.5 \times 1.5 \times 1.5$ cubits. ${ }^{155}$ We know that the mercy seat was decorated elaborately with gold and two cherubs, but Scripture does not report its height. We only learn that the dimensions of its lid were $2.5 \times 1.5$ cubits, equivalent to the length and height of the ark itself. Reland observed that B. Bava bathra 14a translated 1 cubit into 6 handbreadths and stated that it was 15 handbreadths long, 9 handbreadths wide, and 9 handbreadths high. Since B. Sanh. 7 a reported that

\footnotetext{
$15^{\circ} \quad$ Ruderman, Early Modern Jewry, p. 179.

$15^{1}$ Reland, Oratio De usu antiquitatum sacrarum, p. 9: 'Illa fuit infelicitas priorum temporum quum qui ad Hebraeas literas animum appellerent ab Judaeorum partibus stare crederentur'.

$15^{2}$ Ibid., pp. 8-9: 'Edocemur aliunde, si scripta Judaeorum consulimus, multa tum in Veteri tum in Novo Instrumento insigni luce perfundi. Quidni ergo ab iisdem in pluribus opem petimus?'

153 The list of publications on the subject is massive, although a substantial monograph on philosemitism in the Early Modern period is still missing. See, for instance, Coudert, 'Seventeenth-Century Christian Hebraists'; more recently, Melamed, 'The Revival of Christian Hebraism'; Sutcliffe, 'A Philosemitic Moment?'

154 Supplement Du Journal Des Sçavans (30 January 1709), p. 126: 'L'Auteur emprunte ce qu'il nous apprend sur ces quatre points, non seulement de l'Ecriture sainte, mais du Thalmud, \& des autres Ecrivains Hebreux'.

155 Exod. 25:10-22.
} 
the total height of the ark measured 10 handbreadths, then the height of its lid must have been 1 handbreadth. ${ }^{156}$

The question remains, of course, of how this information translated into the Early Modern classroom. ${ }^{157}$ There is plenty of evidence that Reland's students were just as troublesome or studious as students today: they drank too much, studied too little, and picked professors not for the quality of the lecture but for the jokes they made. ${ }^{158}$ When the Hebraist Hermann Samuel Reimarus (1694-1768) from Hamburg enrolled at the University of Jena, he complained about the poor proficiency in Latin of his fellow classmates. ${ }^{159}$

If students then were struggling with Latin, what assumption can we make about their proficiency in Greek or Hebrew, let alone Arabic or Syriac? Granted, just as they do today, some disciplines served as a natural weed-out, but the question still remains as to how students were able to follow a lecture that required proficiency in more than just one classical language. It is almost impossible to come up with a general scenario on the practicalities of Early Modern teaching. First of all, there was the distinction between public and private teaching. Then there was the actual practice of teaching and lecturing, which included dictation, discussion, and quizzing. ${ }^{160}$ One reason that may explain the popularity of Reland's Antiquitates was its concise nature and

156 Reland, Antiquitates, pp. 49-50: 'Erat autem cubitus sex palmorum אמה בת ששה טפחים, uti dicitur Gem. Bava bathra. 14:1. Gem. Hier. Sota. 22.3. Sic ut cum operculo altitudo arcae fuerit 1o palmorum. Operculi enim altitudo unius palmi fuisse legitur in Gem. Nidda. 26.2. Gem. Schabbath. 92.1. Gem. Sanhedrin 7.1. Observant Judaei, quum reliquorum fere vasorum Tabernaculi memoretur in sacro Codice longitudo, latitudo atque alitudo, operculi altitudinem non dedisse Mosen'.

157 See the discussion of the practicalities of teaching and student experience in my Hermann Samuel Reimarus (1694-1768), pp. 28-61 and pp. 62-110.

$15^{8}$ See for instance, the account in Müller, Meines Lebens Vorfälle, part 1, p. 58 : 'Unter anderen nannte er den Herrn Professor Stellwagen, welcher den grösten Applausum, aber nur bei den meisten seiner Poßen wegen habe; denn die meisten derer Herren Studenten eilten nur dahin, wo es was zu lachen gäbe'; on the subject of student culture see Klenke et al. (eds), Von Professorenzirkeln.

159 Letter from Hermann Samuel Reimarus to Christoph Wolf, 16 June 1714, Staats-und Universitätsbibliothek Hamburg, Supellex 119, fol. 417v-418r: 'Ceteri vero plerique omnes nil agunt aliud, quam ut ea, quae charta in papyrum descripsere ipsi, dictitent in calamum l[ingua] Latina Buddei verba, germanicis iisque amplioribusque reddere conentur, cujus quidem rei non ipsorum imperitia, sed summa ignorantia plerumque discentium et incredibilis stupor causa est.Hi enim ultra prima Grammatices et pietatis elementa vix quicquam progressi, e Vicinia huc advolant, mox, ubi summa capita Doctrinarum, ut canes Nilum, degustaverint, rursus abituri [...]. Multa mihi promisseram de Bibliotheca hac Jenensi, et est profecto satis magno librorum apparatu instructa, sed quoniam disjecta sunt omnia atque inter se permixta, paucis huc usque usui esse potuit [...]'.

Van Miert, Humanism in an Age of Science, pp. 115-166. 
organization. As I have shown elsewhere, Reland's book was most probably used over the course of more than one academic term. For instance, a professor may have lectured publicly on Reland's de locis sacris, but held private lectures in his home on de rebus sacris during the same semester. ${ }^{161}$ During the actual 'class meeting', the professor may have read slowly a passage from Reland, followed by his own comments.

What these comments were, we can discover by looking at a number of extant lecture notes. One of them, a manuscript at the Royal Library in Copenhagen, is entitled Observationes ad Hadriani Relandi Antiquitates Sacrae Veterum Hebraeorum datae Celeberrimo H.S. Reimarus, LL. OO. PP. Gymnasii Hamburgi. ${ }^{162}$ It is based on the lecture notes by the Hebraist and closet Enlightenment radical Reimarus, who was teaching at the Gymnasium illustre in Hamburg and dates from 1729. The other set is published as Vorlesungen über die Jüdischen Alterthümer nach Anleitung Hadr. Relands Antiquitatum sacr. veterum Hebraeorum and is based on the lecture notes by the Hebraist and theologian from Halle, Johannes Simonis (1698-1768). ${ }^{163}$ Comparing these two lectures even peripherally reveals that Reland's textbook allowed for a number of contexts and teaching formats. In the second chapter of de locis sacris, for instance, Reland describes the city of Jerusalem. According to B. Bava Kamma $82 \mathrm{~b}$, it held the status as a holy city. Reland then provides a list of prohibitions and stipulations, all based on his rabbinic sources. He pointed out that corpses could not be held overnight in the city, including bones or tombs for the dead, except in the cases of David and the prophetess Huldah. No residences of converts were permitted, nor, perplexing though it may sound, were houses with balconies. Neither gardens nor dung heaps were allowed; likewise there could be no agricultural activities such as the raising of chickens. Fruit-bearing trees could only be planted at a distance of 25 cubits from the city, ornamental trees only at a distance of 50 cubits. ${ }^{164}$

While some stipulations in this list make sense, others must have seemed perplexing to the students. After the passage was read to the students, professors

\footnotetext{
161 Groetsch, Reimarus, pp. $75^{-77 .}$

162 Reimarus, Observationes.

163 Simonis, Vorlesungen über die Jüdischen Alterthümer.

164 Reland, Antiquitates, pp. 14-15: 'In Gem. Bava kama. 82.2 Hierosylomae privilegia prae aliis urbibus terrae Sanctae haec recensentur. Non pernoctare illic cadaver, (confer librum Siphra fol. 29o. I.) nec ossa mortui ei inferri: non locari aedes: non concedi illic habitationem prosyleto inquilio: non esse in ea hortos: non feri nec arari, nec plantari arbores (quid? quod arbores frugiferas ad 25 cubitos ad urbe removendas, infrugiferas ad 5 o legatur in Bava bathra 11.7) nulla esse illic sterquilinia, Meniana aedium, fornaces calcarias, non ali gallos gallinaceos $[\ldots]$ '.
} 
provided their own explanation. The students in Simonis's classroom would learn that there were a total of 16 such stipulations in the B. Bava Kamma alone. Citing Johann Christoph Wagenseil's commentary on the Mishna Sotah, Simonis reported that supposedly nobody was ever bitten by a snake nor by a scorpion in the holy city. He told his students that the reason for the prohibition against planting gardens was that the use of manure and fertilizers might produce an unpleasant stench.

More problematic, of course, was explaining the prohibition against raising chickens. According to Simonis, chickens had a predilection to scratch around'. This 'would easily bring bones of dead bodies to the surface', which would 'defile the city'.165 The students in Hamburg heard nothing about snakes or scorpions. To Reimarus, it seemed more important that students should learn about the ancient practice of burial and corpse handling. Rather than providing an elaborate explanation of Jewish law, the Hebraist from Hamburg stated only briefly that the presence of corpses overnight was believed to defile the city. Instead, Reimarus provided a historiographical list of key sources that included Jean Le Clerc's commentary on Leviticus, Johann Kirchmann's monograph about ancient Roman funeral rites, and William Outram's book on ancient Jewish sacrificial practices, which indicates that he viewed ancient Judaism in a much broader ancient cultural context. ${ }^{166}$ Both professors, however, could not ignore the implications these regulations had for their Christian student audience. If chickens were not allowed in the holy city, then how could Peter have heard a rooster crow twice after denying Jesus three times? ${ }^{167}$ Here, the professor from Halle was the most vocal. Simonis expressed his doubts about the trustworthiness of the Talmudists in the first place. However, rather than denouncing the latter as liars, Simonis explained to his students, some Christian scholars, including Reland himself, tried to reconcile both accounts.

165 Simonis, Vorlesungen über die Jüdischen Alterthümer, pp. 39-40: 'Solche Vorzüge der Stadt Jerusalem zählen die Juden 16 in der Gemara Bava Kama, wozu sie in Tractatu Avoth noch andere setzen; als daß niemals eine Schlange oder Scorpion Jemanden daselbst beschädiget habe, daß niemals eine Feuerbrunst darin gewesen sey und dergleichen, conf. Wagenseil ad Sota p. goo seq. Die Ursache, warum man keine Gärten in der Stadt hätte anlegen dürfen, soll gewesen seyn, damit durch das Düngen derselben und durch faule stinkende Kräuter kein Gestank verursacht würde. Hühner habe man deswegen nicht halten dürfen, weil dieselben gerne scharren und leicht Knochen von todten Körpern hätten hervorkratzen und also die heil. Stadt verunreinigen können'.

166 Reimarus, Observationes, fol. 13: 'Non p[er]noctare ibi cadaver, quia cadavere polluebantur, vid. Cleric. ad Lev. 21 1. 11 et Kirchmann, de funeribus Romanis lib. 6. C. 2 et 3. [?] Outram, de sacrificiis, l. 6 [...]'; see Le Clerc, Commentarius; Kirchmann, De funeribus Romanorum; Outram, De sacrificiis.

167 Mk. 14:68-72. 
In March 1709 Reland gave a public talk entitled De galli cantu Hierosolymis audito [On the crowing of the rooster that was heard in Jerusalem], which was published nine years later. Reland argued then that there was no reason to distrust either the New Testament or Jewish sages. Although Jewish law prohibited raising chickens within the city limits, the rooster could have been heard from outside of the city. In spite of the prohibition, there were scenarios of roosters living within the city limits regardless. For instance, the Romans were not bound by Jewish laws. But even among the Jews there may have been some people who did not always play by the rules and disregarded the law. ${ }^{168}$ Although Reland's argument was convincing to most Early Modern scholars and theologians, some came up with alternative scenarios. Simonis noted that some proposed that the Greek term $\dot{\alpha} \lambda \dot{\varepsilon} \kappa \tau \omega \rho$ was mistranslated. Rather than a reference to a rooster, it may actually have referred to one of the priestly officials, the praefectus temporibus, who was in charge of making sure that priests assumed their respective tasks each morning in a timely fashion. Essentially, this official was a 'walking wake-up call'. ${ }^{169}$ Others, such as the Swiss theologian from Bern, Johann Georg Altmann (1695-1758), apparently went as far as to indentify the $\dot{\alpha} \lambda \dot{\varepsilon} \kappa \tau \omega \rho$ as the holy city's nightwatchman. Altmann's interpretation was again rejected by the theologian Daniel Gottfried Werner (1695-1752), who gave a public talk at Jena in which he came out in support of Reland's original explanation. ${ }^{170}$

It would be difficult to overstate the influence Reland's Antiquitates sacrae had on generations of Christian Hebraists and theologians. A testimony to its importance was its inclusion in the second volume of Blasius Ugolini's massive Thesaurus antiquitatum sacrarum (1744). Ugolini's compilation included only the crème de la crème of biblical scholarship. There, Reland was in the company of the giants in the field, such as Buxtorf, Huet, Bochart, Selden, and Spencer. Reland's Antiquitates sacrae provided a plausible and concise structure that allowed for a contextualization of revelation history, and it justifiably

168 Reland, Oratio De galli cantu, p. 28: ‘[...] nihilominus gallum extra Hierosolymas canentem in urbe audiri potuisse, \& eam fuisse conditionem illorum temporum, ut varii modi concipi queant, quibus etiam intra urbem galli existere vel ali a Romanis, aut ab ipsis Judaeis, leges patrias negligentibus, potuerint'.

169 Simonis, Vorlesungen über die Jüdischen Alterthümer, p. 40: 'Wir finden aber in der Leidensgeschichte das Gegentheil, da wir lesen, daß der Hahn gekrähet habe. Damit nun die talmudischen Lehrer nicht zu Lügnern werden, haben einige Gelehrte unter den Christen verschiedenes hervorgesucht, beydes mit einander zu vereinigen [...]. Andere meinen, durch $\alpha \lambda \varepsilon \dot{\varepsilon} \chi \tau \omega \rho$ sey der Praefectus temporibus zu verstehen, der die Priester des Morgens aufwecken mußte [...] wogegen aber Altmann in Biblioth. Bremens. Class v. p. 45 seq. verschiedenes einwendet und dadurch einen Nachtwächter verstehet'.

Werner, Gallus gallinaceus. 
became the standard textbook on the subject. By providing, for instance, a precise description of ancient Jewish sacrificial practices, Reland supplied the framework for theologians to offer a typological reading to their students. It could be, and was, used by Lutherans, Reformed, and Roman Catholics alike. This was certainly Reland's goal. At the same time, each chapter offered an opportunity for each professor to demonstrate his own learning by touching upon recent debates and scholarly controversies. In this respect, the book provided a cluster of theologically relevant topics that were talking points in the academy and were producing a massive body of scholarly literature. For obvious reasons carrying around Ugolini's thirty-four volume thesaurus was not really practical. Reland's work was thus also a way of dealing with an overload of information and organizing knowledge in 'the philological republic of Christian Hebraism'.

However, as we have seen with the example of the rooster, Christian Hebraists such as Reland also laid the foundations for the de-theologization of Scripture, because their inclusion of sources outside of Scripture drew attention to instances where revealed history did not fit into verifiable and verified cultural clusters of the ancient world. The larger the body of sources that provided an alternative story to the generally accepted biblical account was, the harder it became for the theological establishment to salvage the account on the same playing field since that would require the ability to provide credible alternative examples from the ancient world in support of the biblical narrative. Ironically then, the theological classrooms at Leiden, Utrecht, Hamburg, or Jena became a space of profanation and secularization. The body of knowledge provided by Christian Hebraists such as Reland opened the door to reveal to students weaknesses in the biblical narrative that could not be simply explained away. Eventually, the massive philological data contradicting the revealed account tilted the balance in the minds of these young students in favour of a secularized general model of the ancient world where the culture of ancient Israel and ancient Christianity stood on the same plane as those of ancient Egypt, Persia, Greece, or Rome. ${ }^{171}$

Similarly, it would not be exaggerated to classify Reland's scholarly work, especially his work in the field of the geographia sacra, as the Early Modern precursor to modern archaeology, regardless of any charges of anachronism. In this regard, Reland's work paved the way for later models of biblical scholarship by Immanuel Benzinger, Paul Volz, or Roland De Vaux. ${ }^{172}$ Reland practised

171 See, for instance, Mulsow, Radikale Frühaufklärung, pp. 12-109.

172 Volz, Die Biblischen Altertümer; Benzinger, Hebräische Archäologie; De Vaux, Les Institutions de l'Ancien Testament. 
cutting-edge biblical scholarship, which was the equivalent of work in the field of biblical (or Syro-Palestinian) archaeology. He traced ancient cities, identified mountains, and followed the course of lost or invisible rivers. In this process Reland combined expert philological mastery with new 'archaeological' insights from the field provided by travel accounts and the recent philological scholarship of the day that included work with objects such as ancient coins. Almost every contemporary reviewer celebrated Reland's Palaestina as a milestone in the field, especially his inclusion of newly-drawn maps: it was as transformative to the field then as GIs has been now.

Reland's influence persisted for decades thereafter. ${ }^{173}$ Similar to what Ptolemy was to Columbus and Bochart was to the participants of the Danish Expedition to Arabia, Reland's Palaestina illustrata became the guidebook for the father of modern biblical geography, Edward Robinson, during his travels to Palestine over one hundred years later. ${ }^{174}$ In fact, it is utterly perplexing that the otherwise excellent, voluminous series Hebrew Bible/Old Testament: The History of Its Interpretation has failed to recognize Reland's milestone in the history of biblical geography. In his contribution to the section on nineteenthcentury biblical interpretation, Steven W. Holloway dismisses Reland's map for its crude accuracy, where major biblical/classical names are plotted 'within $5^{-10}$ miles of the actual site. ${ }^{175}$ In fact, Holloway's dismissal of Early Modern savants such as Reland is rather symptomatic of the field of modern biblical

173 Le Clerc, Bibliotheque ancienne et moderne, vol. 2 no. 2, pp. 36o-361: 'C'est ici une des meilleures descriptions de la Palestine, que l'on ait encore vuës, \& qui seroit aussi parfaite, qu'elle le pourroit être; si les Anciens, qui nous ont instruits de ce païs-là, eussent autant pris de peine à nous le décrire, que Mr. Réland a employé se soins \& d'exactitude à profiter des lumieres, qu'il a trouvées dans leurs Ecrits'; Deutsche Acta Eruditorum oder Geschichte der Gelehrten, vol. 31, p. 523: 'Herr Reland ist ein Mann, dem die Orientalischen Sprachen nicht weniger als die Griechische geläuffig sind, drum hat er nicht mit frembden Augen sehen dürffen, wie in der Geographie und Historie sonst gar offt geschieht, da ihrer etliche wie die Spanier, die Brillen voneinander erben, indem sie solche nicht zum sehen, sondern zum Staat und zur Mode tragen. Unser Autor ist durchgehende Original, wie man solches aus seiner Schreib-Art leicht erkennet, da er überall Stellen der Alten und zwar mit Verstande anführt, sich wenig bekümmert erzeigt, wo ein Neuer gefehlt und angestossen [...]. Viele, die Land-Charten in der alten Geographie machen, haben genung, wenn sie nur sein viele Nahmen drauf setzen, wo sie eigentlich gelegen seyn. Um Berge und Ebenen bekümmern sie sich gar nicht [...]. Diese Mode ist Herrn Relanden zu gemein gewesen. Er hat demnach auf seiner Charte von Palästina zwar weniger Oerter als andre, dieselben aber um so viel gewisser gesetzt [...]'.

174 On Robinson, see Soler, Edward Robinson; also Davis, Shifting Sands, pp. 4-12.

175 See Holloway, 'Expansion of the Historical Context', p. 104. 
scholarship. ${ }^{176}$ In their efforts to strive for 'scientific' accuracy and against the backdrop of ideological quibbles, modern biblical scholars and theologians have tended to emphasize the power of recent archaeological data and, with a few noteworthy exceptions, have been almost completely ignorant of the philological scholarship of earlier generations of biblical scholars and Hebraists. ${ }^{177}$ They are neglecting the scholarly heritage upon which they have built, and assuming that their work emerged fully-formed, as Athena did. The example of Adriaan Reland may prove otherwise.

\section{Bibliography}

\section{Manuscript Collections}

Letter from Hermann Samuel Reimarus to Christoph Wolf, 16 June 1714, Staats-und Universitätsbibliothek Hamburg, Supellex 119: fol. 417v-418r.

Reimarus, H.S., Observationes ad Hadriani Relandi Antiquitates S, Veterum Hebraeorum, Royal Library Copenhagen, Kall, 311, $4^{\circ}$.

\section{Sources}

Acta Eruditorum vol. 2, Leipzig, Johann Friedrich Gletisch and Son, 1710.

Allgemeines Gelehrten-Lexicon [...], vol. 2: D-L, Leipzig, Christian Gottlieb Jöcher, 175 . Bertram, B.C., De politia iudaica tam civili quam ecclesiastica, iam inde a suis primordiis, hoc est, ab orbe condito, repetita, Geneva, Eustathius Vignon, 1580.

Bochart, S., Hierozoicon sive bipertitum opus de animalibus S, Scripturae, Frankfurt, Balthasar Christoph Wust, 1675 .

Bochart, S., Geographia sacra, seu Phaleg et Canaan [...], 3rd edn., Utrecht, Willem vande Water, 1692.

Braunius, J., בגדי כהנים id est, vestitus sacerdotum Hebraeorum, Amsterdam, Johannes van Someren, 1680.

Braunius, J., Doctrina foederum, sive systema theologiae didacticae \& elencticae, Amsterdam, Abraham van Someren, 1691.

Burmann, C., Traiectum eruditum, virorum doctrina inlustrium qui in urbe trajecto, et regione trajectensi nati sunt, sive ibi habitarunt, vitas, fata et scripta, Utrecht, Jurrianus van Paddenburg, 1738.

Calmet, A., Commentaire literal sur tous les livres de l'Ancien ed du Nouveau Testament, 24 vols., Paris, Pierre Emery, 1707-1720.

${ }_{176}$ Similarly, but in a different context, Anthony Grafton criticized the ignorant dismissal of past scholarship. See Grafton, 'From Politian to Pasquali', p. 176.

177 See Groetsch, Reimarus, pp. 308-309. 
Carpzov, J.G., Critica sacra Veteris Testamenti, Leipzig, Johann Christian Martin, 1728.

Cunaeus, P., De republica Hebraeorum libri III, Leiden, Elzevier, 1617.

Cuper, G., Lettres De Critique De Litterature, D'Histoire, \& c, Ecrites A Divers Savans De L'Europe, Amsterdam, Jacob Wetstein, 1743.

Deutsche Acta Eruditorum oder Geschichte der Gelehrten, vol. 31, Leipzig, Johann Friedrich Gleditsch und Sohn, 1715.

Einem, J.J. von, Selectae animadversiones ad Johannis Clerici scripta, Magdeburg, Siegler, 1735 .

Fabricius, J.A., Bibliographia antiquaria sive Introductio in notitiam scriptorum [...], 3rd edn., Hamburg, Johann Carl Bohn, 176o.

Flacius, M., Clavis Scripturae seu De sermone scrarum literarum ... altera pars [...], Leipzig, Johann Justus Erythropilus, 1695.

Forsetzung undErgänzungenzu Christian GottliebJöchers allgemeinem Gelehrten-Lexico, vol. 2: C-J, Leipzig, Adelung, 1787.

Glassius, S., Philologia sacra, qua totius SS, Veteris et Novi Testamenti Scripturae, tum sensus et genuinae interpreationis ratio et doctrina libris quinque expenditur ac traditur, Leipzig, Johann Friedrich Gleditsch, 1713.

Goodwin, Th., Moses and Aaron: Civil and Ecclesiastical Rites used by the ancient Hebrews, 11th edn., London, S. Griffin, R. Scott, T. Basset, J. Wright, and R. Chiswel, 1678.

Goodwin, Th., Moses et Aaron seu civiles \& ecclesiastici ritus illustrati, emendati \& praecipuis thematibus aucti studio Joh. Henr. Hottingeri, Frankfurt, Dominicus von Sande, 1710.

Grosses vollständiges Universal-Lexicon aller Wissenschafften und Künste [...], vol. 19, Halle and Leipzig, Johann Heinrich Zedler, 1739.

Horne, Th.H., Introduction to the Critical Study and Knowledge of the Holy Scriptures, vol. 2, 5 th American Edition, Philadelphia, Desilver jr, \& Thomas, 1833.

Hottinger, J.H., 'ЕI $\Sigma \mathrm{A} \Omega \Gamma \mathrm{H}$ ad studium antiquitatum Judiacarum' in Th. Goodwin, Moses et Aaron seu Civiles \& ecclesiastici ritus illustrati, emendati \& praecipuis thematibus aucti studio Joh. Henr. Hottingeri, Frankfurt, Dominicus von Sande, 1710.

Huet, P.-D., Tractatus de situ paradisi terrestris [...], Utrecht, Willem vande Water, 1698. Huet, P.-D., Mémoires de Daniel Huet: Évêque d'Avranches, translated by Charles Nisard, Paris, Ch. Lahure, 1853 .

Jennings, D., Jewish Antiquities or A Course of Lectures on the First Three Books of Godwin's Moses and Aaron, vol. 1, London, J. Johnson and B. Davenport, 1766, Journal Des Sçavans, December 1746.

Le Clerc, J., Bibliotheque ancienne et moderne, vol. 2 no. 2, Amsterdam, David Mortier, 1714 .

Le Clerc, J., Commentarius in Mosis prophetae libros quinque cum ejusdem versione et paraphrasi perpetua, dissertationibus item criticis atque tabulis chronologicis et geographicis, Tübingen, Johann Georg Cotta, 1733. 
Leydecker, M., De republica Hebraeorum libri XII, Amsterdam, Isaac Stokmans, 1704. Lightfoot, J., Horae Hebraicae et Talmudicae, Cambridge, Edward Story, 1658.

Magliabechi, A. di, Clarorum Belgarum ad Ant. Magliabechum nonnullosque alios epistolae, vol. 2, Florence, Apollini, 1745 .

Mill, D., Dissertationes selectae, varia s. litterarum et antiquitatis orientalis capita exponentes et illustrantes, Utrecht, Jacob Broedelet, 1724.

Müller, Chr., Meines Lebens Vorfälle und Neben-Umstände, Part 1: Kindheit und Studienjahre (1720-1746), Katrin Löffler and Nadine Sobitrai (eds), Leipzig, Lehmstedt, 2007.

[Nicéron, J.-P.], Mémoires pour servir a l'histoire des hommes illustres dans la Republique des Lettres [...], vol. 1, Paris, Briasson, 1729.

Pélissier, Léon-G, 'Lettres inédites de Gisbert Cuypert (Cuper) à P. Daniel Huet et à divers correspondants (1683-1716)', Mémoires de l'Académie Nationale des Sciences, Arts et Belles-Lettres de Caen, Caen, Henri Delesques, 1903.

Pennis, A., Dissertationis historico-theologicae De sermone Dei in origine universi, pars prima \& secunda, quam favente triuno numine, sub praesidio D. Melchioris Leydeckeri [...], Utrecht, François Halma, 1696.

Rambach, J.J., Institutiones hermeneuticae sacrae [...], Jena, Johann Wilhelm Hartung, 1743 .

Reiske, J.J., Von ihm selbst aufgesetzte Lebensbeschreibung, Leipzig, Buchhandlung der Gelehrten, 1783 .

Reland, A., Dissertationis historico-theologicae De sermone Dei in origine universi, parstertia \& ultima, quam favente triuno numine, sub praesidio D. Melchioris Leydeckeri [...], Utrecht, François Halma, 1696.

Reland, A., Analecta rabbinica, comprehendentia libellos quosdam singulares \& alia quae ad lectionem \& interpretationem commentariorum rabbinicorum faciunt. In usum collegii rabbinici singula post praefationem indicantur, Utrecht, Thomas Appels, 1702.

Reland, A., Elenchus philologicus, quo praecipua, quae circa textum et versiones Sacrae Scripturae disputari inter philologos solent breviter indicantur. In usum studiosae iuventutis, Utrecht, William Broedelet, 1706.

Reland, A., Dissertationum miscellanearum pars prima, editio secunda, Utrecht, William Broedelet, 1713 .

Reland, A., Oratio De usu antiquitatum sacrarum quum ad professionem earum acce$\operatorname{deret}[. .$.$] Utrecht, William vande Water, 1713$.

Reland, A., Palaestina ex monumentis veteribus illustrata, 2 vols., Utrecht, William Broedelet, 1714.

Reland, A., De religione Mohammedica libri duo. Editio altera auctior, Utrecht, Willem Broedelet, 1717 .

Reland, A., Antiquitates sacrae veterum Hebraeorum breviter delineatae, editio tertia, Utrecht, Willem Broedelet, 1717. 
Reland, A., Oratio De galli cantu Hierosolymis audito [...], Rotterdam, Petrus van Marienhof, 1709 .

Rhenferd, J., Dissertatio philologica De ratione observandi genuinam vocabulorum Hebraicorum significationem, Franeker, François Halma, 1704.

Rhenferd, J., Oratio De fundamentis \& principiis philologiae sacrae, in J. Rhenferd, Opera philologica, dissertationes exquisitissimi argumenti constantia, Utrecht, Willem vande Water, 1722, pp. 917-941.

Rhenferd, J., Rudimenta grammaticae harmonicae linguarum orientalium, in Opera philologica [...] dissertationes, Utrecht, Willem vande Water, 1722.

Saubertus, J., De sacrificiis veterum conlectanea historico-philologica, Leiden, Jordan Luchtmans, 1699.

Schultens, A., Opera minora, animadversiones eius in Jobum, et varia loca V.T. [...], Leiden, Johann Le Mair, 1769.

Schultens, A., Commentarius in Librum Jobi in compendium redegit et observationes criticas atque exegeticas, Halle and Magdeburg, Johann Jacob Curtius, 1773.

Semler, J.S., Lebensbeschreibung von ihm selbst abgefaßt, pars 1, Halle, n.p., 1781.

Serrurier, J., Oratio funebris in obitum viri celeberrimi Hadriani Relandi, antiquitatum sacrarum et linguarum orientalium professoris ordinarii, recitata ipsis nonis Martiis MDCCXVIII, Utrecht, Willem vande Water, 1718.

Sigonio, C., De republica Hebraeorum libri VII [...], Bolognia, Johannes Rosius, 1582.

Simonis, J., Vorlesungen über die Jüdischen Alterthümer nach Anleitung Hadr. Relands Antiquitatum sacr. veterum Hebraeorum, Halle, Johann Jacob Curt, 1769.

Spanheim, F., Introductio ad geographiam sacram patriarchalem, israëliticam, \& christianam, hancque cum per Romanum omne Imp. ante \& post Constantinum M. tum per provincias barbaricas in usus studiosae iuventutis, Leiden, Daniel van Gaesbeeck, 1679 .

Supplément du Journal des Sçavans (30 January 1709).

Supplément du Journal des Sçavans (3o September 1709).

Vitringa, C., 'Typi crucifixioni Christi, qui in Lege \& Prophetis extant, incipiunt proponi \& explicari', in Observationum sacrarum libri sex [...], vol. 1., Franeker, Wibius Bleck, 1712, pp. 409-419.

Werner, D.G., Gallus gallinaceus vigil Petri monitor ex veterum auctoritate pristinae formae restitutus, Jena, Marggraf, 1723 .

\section{Studies}

Asselt, W.J. van, 'Leydekker, Melchior', in Biografisch lexicon voor de geschiedenis van het Nederlandse protestantisme, vol. 4, Kampen, Kok, 1998, pp. 307-310.

Bartlett, J., Mapping Jordan Through Two Millennia, Leeds, Maney, 2008.

Bartolucci, G., La repubblica ebraica di Carlo Sigonio, Florence, Olschki, 2007. 
Bartolucci, G., 'Carlo Sigonio and the "Respublica Hebraeorum”: A Re-evaluation', Hebraic Political Studies, vol. 3, no. 1, 2008, pp. 19-59.

Benzinger, I., Hebräische Archäologie, Leipzig, Verlag von Eduard Pfeiffer, 1927.

Bevilacqua, A., The Republic of Arabic Letters: Islam and the European Enlightenment, Cambridge, MA, The Belknap Press of Harvard University Press, 2018.

Blair, A., Too Much To Know: Managing Scholarly Information before the Modern Age, New Haven and London, Yale University Press, 2010.

Brockliss, L., Calvet's Web:Enlightenment and the Republic ofLetters inEighteenth-Century France, Oxford and New York, Oxford University Press, 2001.

Bultmann, Chr. and L. Danneberg (eds), Hebraistik-Hermeneutik-Homiletik: Die "Philologia Sacra" im frühneuzeitlichen Bibelstudium, Berlin, De Gruyter, 2011.

Burnett, C. et al. (eds), The Teaching of Arabic in Early Modern Europe, Leiden and Boston, Brill, 2017.

Butler, R., 'Maundrell, Henry (bap. 1665, d. 1701), Church of England Clergyman and Traveller in the Middle East', 23 Sep. 2004, https://doi.org/10.1093/ref:odnb/18378 (accessed 21 Feb. 2020).

Coudert, A., 'Seventeenth-Century Christian Hebraists: Philosemites or Antisemites', in A. Coudert et al. (eds), Judeo-Christian Intellectual Culture in the Seventeenth Century: A Celebration of the Library of Narcissus Marsh (1638-1713), New York, Springer, 1999, pp. 43-69.

Davis, T., Shifting Sands: The Rise and Fall of Biblical Archaeology, Oxford and New York, Oxford University Press, 2004.

De Vaux, R., Les Institutions de l'Ancien Testament, 2 vols., Paris, Les Editions du Cerf, $195^{8 .}$

Dunkelgrün, Th., The Multiplicity of Scripture: The Confluence of Textual Traditions in the Making of the Antwerp Polyglot Bible (1568-1573), PhD Thesis, University of Chicago, 2012.

Goldgar, A., Impolite Learning: Conduct and Community in the Republic of Letters, 16801750, New Haven, Yale University Press, 1995.

Grafton, A., 'From Politian to Pasquali', Review of The Classical Text: Aspects of Editing in the Age of the Printed Book, by E.J. Kennedy, The Journal of Roman Studies, vol. 67, 1977, pp. 171-176.

Grafton, A. 'Spinoza's Hermeneutics: Some Heretical Thoughts', in D. van Miert et al. (eds), Scriptural Authority and Biblical Criticism in the Dutch Golden Age, Oxford and New York, Oxford University Press, 2017, pp. 177-196.

Groetsch, U., 'The Scholar as Whoremonger: Petrus Burman (1668-1741) and the Dark Abysses of Classical Scholarship', in M. Mulsow (ed.), Kriminelle-FreidenkerAlchemisten: Räume des Untergrunds in der Frühen Neuzeit, Cologne, Weimar; Vienna, Böhlau Verlag, 2014, pp. 557-573. 
Groetsch, U., Hermann Samuel Reimarus (1694-1768): Classicist, Hebraist, Enlightenment Radical in Disguise, Leiden and Boston, Brill, 2015.

Groetsch, U., 'Adversus Haereticos: Sebastian Edzard's Epic Battle for Souls', in J.A. Steiger et al. (eds), Das Akademische Gymnasium zu Hamburg (gegr, 1613) im Kontext frühneuzeitlicher Wissenschafts-und Bildungsgeschichte, Berlin and Boston, De Gruyter, 2017, pp. 137-162.

Hardy, N., Criticism and Confession: The Bible in the Seventeenth Century Republic of Letters, Oxford and New York, Oxford University Press, 2017.

Hoek, P.C., 'Melchior Leydecker (1642-1721): Reformed Scholasticism of a Catholic Character in Calvin's Footsteps', Church History \& Religious Culture, vol. 91, nos. 1-2, 2011, pp. 193-201.

Holloway, S., 'Expansion of the Historical Context of the Hebrew Bible/Old Testament', in Magne Saebø (ed.), Hebrew Bible/Old Testament: The History of its Interpretation, vol. 3, no. 1: The Nineteenth Century, Göttingen, Vandenhoeck \& Ruprecht, 2013, pp. 90-118.

Ilic, L., Theologian of Sin and Grace: The Process of Radicalization in the Theology of Matthias Flacius Illyricus, Göttingen, Vandenhoeck \& Ruprecht, 2014.

Katchen, A., Christian Hebraists and Dutch Rabbis: Seventeenth Century Apologetics and the Study of Maimonides' Mishneh Torah, Cambridge, MA, Harvard University Press, 1985 .

Klein, D. and B. Platow (eds), Wahrnehmung des Islam zwischen Reformation und Aufklärung, Munich, Wilhelm Fink Verlag, 2008.

Klenke, D. et al. (eds), Von Professorenzirkeln, Studentenkneipen und akademischen Networking, Köln, Böhlau, 2016.

La Vopa, A., Grace, Talent and Merit: Poor Students, Clerical Careers, and Professional Ideology in Eighteenth-Century Germany, New York, Cambridge University Press, 1988.

Laplanche, F., 'Christian Erudition in the Sixteenth and Seventeenth Centuries and the Hebrew State', Hebraic Political Studies, vol. 3, no. 1, 2008, pp. 5-18.

Levitin, D., 'From Sacred History to the History of Religion: Paganism, Judaism, and Christianity in European Historiography from Reformation to "Enlightenment", The Historical Journal, vol. 55, no. 4, 2012, pp. 1117-116o.

Loop, J., Johann Heinrich Hottinger: Arabic and Islamic Studies in the Seventeenth Century, Oxford and New York, Oxford University Press, 2013.

Massimi, J.-R., 'Montrer ed démontrer: autour du Traité de la situation du paradis terrestre de P.D. Huet (1691)', in A. Desreumaux and F. Schmidt (eds), Moïse géographe: recherches sur les représentations juives et chrétiennes de l'espace, Paris, Librairie Philosophique J. Vrin, 1988, pp. 203-225.

Matar, N., 'The Sufi and the Chaplain: 'Abd al-Ghanī al-Nābulusī and Henry Maundrell', in J.A. Hayden and Nabil Matar (eds), Through the Eyes of the Beholder: The Holy Land, 1517-1713, Leiden and Boston, Brill, 2012, pp. 164-184. 
Melamed, A., 'The Revival of Christian Hebraism in Early Modern Europe', in J. Karp and A. Sutcliffe (eds), Philosemitism in History, New York and Cambridge, Cambridge University Press, 2011, pp. 49-66.

Miert, D. van, Humanism in an Age of Science: The Amsterdam Athenaeum in the Golden Age, 1632-1704, Leiden and Boston, Brill, 2009.

Miert, D. van, The Emancipation of Biblical Philology in the Dutch Republic, 1590-1670, Oxford and New York, Oxford University Press, 2018.

Mulsow, M., Radikale Frühaufklärung in Deutschland: 1680-1720, vol. 1, Moderne aus dem Untergrund, Göttingen, Wallstein Verlag, 2018.

Nelson, E., The Hebrew Republic: Jewish Sources and the Transformation of European Political Thought, Cambridge, MA, Harvard University Press, 2010.

Neuman, K., 'Political Hebraism and the Early Modern "Respublica Hebraeorum": On Defining the Field', Hebraic Political Review, vol. 1, no. 1, 2005, pp. 57-70.

Rooden, P. van, “Willem Surenhuys" Translation of the Mishna and the Strange Death of Christian Hebraism', in P. Schäfer and I. Wandrey (eds), Reuchlin und seine Erben: Forscher, Denker, Ideologen und Spinner, Ostfildern, Jan Thorbecke Verlag, 2005, pp. 98-109.

Ruderman, D., Early Modern Jewry: A New Cultural History, Princeton, NJ, and Oxford, Princeton University Press, 2010.

Scafi, A., Mapping Paradise: A History of Heaven on Earth, Chicago, Chicago University Press, 2006.

Schenker, A., 'The Polyglot Bibles of Antwerp, Paris and London: 1568-1658', in M. Saebø (ed.), Hebrew Bible Old Testament: The History of its Interpretation, Vol. 2: From the Renaissance to the Enlightenment, Göttingen, Vandenhoeck \& Ruprecht, 2008, pp. 774-784.

Shalev, Z., Sacred Words and Worlds: Geography, Religion, and Scholarship, 1550-1700, Leiden and Boston, Brill, 2012.

Sheehan, J., The Enlightenment Bible: Translation, Scholarship, Culture, Princeton, NJ, and Oxford, Princeton University Press, 2005.

Shelford, A., Transforming the Republic of Letters: Pierre-Daniel Huet and European Intellectual Life, 1650-1720, Rochester, NY, University of Rochester Press, 2007.

Soler, R., Edward Robinson (1794-1863) et l'émergence de l'archéologue biblique, Paris, Geuthner, 2014.

Steiger, J.A., 'The Development of the Reformation Legacy: Hermeneutics and Interpretation of the Sacred Scripture in the Age of Orthodoxy', in M. Saebø (ed.), Hebrew Bible Old Testament: The History of its Interpretation, vol. 2: From the Renaissance to the Enlightenment, Göttingen, Vandenhoeck \& Ruprecht, 2008, pp. 691-757.

Stroumsa, G., A New Science: The Perception of Religion in the Age of Reason, Cambridge, MA, Harvard University Press, 2010. 
Sutcliffe, A., 'A Philosemitic Moment? Judaism and Republicanism in SeventeenthCentury European Thought', in J. Karp and A. Sutcliffe (eds), Philosemitism in History, New York and Cambridge, Cambridge University Press, 2o11, pp. 66-89.

Telfer, C., Wrestling with Isaiah: The Exegetical Methodology of Campegius Vitringa (1659-1722), Göttingen, Vandenhoeck \& Ruprecht, 2016.

Touber, J., 'Biblical Philology and Hermeneutical Debate in the Dutch Republic in the Second Half of the Seventeenth Century', in D. van Miert et al. (eds), Scriptural Authority and Biblical Criticism in the Dutch Golden Age, Oxford and New York, Oxford University Press, 2017, pp. 325-347.

Touber, J., Spinoza and Biblical Philology in the Dutch Republic, 1660-1710, Oxford and New York, Oxford University Press, 2018.

Volz, P., Die Biblischen Altertümer, Tübingen, Calw \& Verlag der Vereinsbuchhandlung, 1914.

Vrolijk, A. and R. van Leeuwen (eds), Arabic Studies in the Netherlands: A Short History in Portraits, 1580-1950, translated by A. Hamilton, Leiden and Boston, Brill, 2014.

Ziskind, J., 'Petrus Cunaeus on Theocracy, Jubilee and the Latifundia', The Jewish Quarterly Review, vol. 68, no. 4, 1978, pp. 235-54. 